\title{
REACTIVITY OF NUCLEOPHILES AND $\alpha$-EFFECT IN SUBSTITUTION PROCESSES AT ELECTRON - DEFICIENCY CENTERS (Part 1)
}

\section{A. F. Popov', I. V. Kapitanov ${ }^{1,3}$, A. A. Serdyuk ${ }^{1,3}$, A. E. Shumeiko ${ }^{1,2^{*}}$}

${ }^{1}$ Institute of Physical Organic Chemistry and Coal Chemistry, L.M. Litvinenko NAS of Ukraine; Kharkiv highway 50, Kyiv 02160, Ukraine.

${ }^{2}$ Institute of Organic Chemistry, NAS of Ukraine; st. Murmanskaya 5, Kyiv 02660, Ukraine

${ }^{3}$ Center for Excellence in Green Chemistry, European Research Area. Department of Chemistry and Biotechnology, Faculty of Science, Tallinn University of Technology, Academia 15, 12618 Tallinn, Estonia

*E-mail: ashumeiko@ukr.net

The review analyzes issues related to the reactivity of nucleophiles and the manifestation of the a-effect in substitution processes at electron-deficient centers. The fundamental aspects of this phenomenon, as well as the possibilities and prospects of using $\alpha$-nucleophiles in systems for the highly efficient degradation of substrates - ecotoxicants of various natures, are discussed. In the first part of the review such aspects were observed: inorganic $\alpha$-nucleophiles as the most effective class of reagents for the decomposition of organic phosphorus compounds, hydroxylamine, its $\mathrm{N}$-alkyl derivatives, oximes, and hydroxamic acids, reactivity of the $\mathrm{HOO}^{-}$anion in the processes of acyl group transfer, reactivity of oximate ions, inorganic $\alpha$-nucleophiles as the basis of formulations for the degradation of neurotoxins, vesicants, and organophosphorus pesticides, design of inhibited acetylcholinesterase reactivators based on hydroxylamine derivatives, ways of structural modification of $\alpha$-nucleophiles and systems based on them. The data on the reactivity of typical inorganic $\alpha$-nucleophiles in the cleavage of acyl-containing substrates, including phosphorus acid esters, which provide abnormally high reaction rates in comparison with other supernucleophiles, are analyzed. Various types of such $\alpha$-nucleophiles, features of their structure and reactivity are considered. It was shown that an important feature of hydroxylamine, oximes, and hydroxamic acids is the presence of a fragment with adjacent $\mathrm{O}$ and $\mathrm{N}(-\mathrm{N}-\mathrm{O}-\mathrm{H})$ atoms containing one or more lone electron pairs, which determines their belonging to the class of $\alpha$-nucleophiles. It has been shown that a many of factors can be responsible for the manifestation of the $\alpha$-effect and its magnitude, the main of which is the destabilization of the ground state of the nucleophile due to repulsion of lone electron pairs, stabilization of the transition state, the unusual thermodynamic stability of reaction products, solvation effects of the solvent, type of hybridization of the electrophilic center, etc.

Key words: functionalized surfactants, $a$-nucleophiles, micellar systems, hydroxylamine, oximes, amidoximes, hydroxamic acids, peroxides. 
INTRODUCTION. The first publication related to the phenomenon, which later became known as the a-effect, dates to 1947. Only 15 years later, Edwards and Pearson [1], having analyzed and generalized a significant amount of experimental material, introduced this term into physical organic chemistry. In its most general form, the essence of the a-effect can be represented as an abnormally high nucleophilic reactivity of a number of compounds, which cannot be predicted from the Brønsted dependence for "normal" oxygen-containing nucleophilic reagents (arylate and alcoholate ions). It was in [1] that compounds containing an electronegative atom with one or more lone pairs of electrons near the nucleophilic center (in the a-position) were isolated from the group of nucleophiles and were called a-nucleophiles (supernucleophiles). Their basic structure is schematically presented below:

$$
\ddot{\mathrm{X}}-\ddot{\mathrm{Y}}
$$

Typical a-nucleophiles include hypochlorite, hydroperoxide anions, hydroxylamine and its derivatives (oxymate, hydroxamate, amidoximate ions), etc. [1, 2, 6, 9, 10, 12-15]. There are two equivalent approaches to assessing the magnitude of the $\alpha$-effect: as the ratio of the rate constants $\mathrm{k}_{\alpha \text {-nuc }} / \mathrm{k}_{\text {nuc }}$ or as the difference $\lg k_{\alpha-\text { nuc }}-\lg k_{\text {nuc }}\left(k_{\alpha-\text { nuc K }}\right.$ and $k_{\text {nuc }}$ are, respectively, rate constants characterizing the reactivity of an $\alpha$-nucleophile and a "normal" nucleophile) at $\mathrm{p} K_{\mathrm{a}}^{\mathrm{a} \text {-nuc }} \approx \mathrm{p} K_{\mathrm{a}}^{\text {nuc }}$. Usually, on the Brønsted dependence, in reactions with electrophilic substrates, the points for such typical a-nucleophiles as $\mathrm{ClO}^{-}$and $\mathrm{HOO}^{-}$ions deviate upwards by $2-3$ logarithmic units $[1,2,6,9,10,15,16]$. In this regard, when creating reagents that effectively break down ecotoxicants (mainly es- ters of phosphorus and sulfur acids), the main efforts of researchers were focused on studying the nature of the $\alpha$-effect $[1,2,6,9,10,12-15]$, which remains one of the intriguing problems of modern physical organic chemistry.

Numerous studies of the anomalously high reactivity of $\alpha$-nucleophiles indicate that there is hardly a single reason for the realization of the $a$-effect. At present, it is believed that $\alpha$-effect can be responsible for: a) destabilization of the ground state of a nucleophile due to the repulsion of lone electron pairs [17], b) stabilization of the transition state $[18,19], \mathrm{c})$ unusual thermodynamic stability of the reaction products [20-23] and d) differentiating solvation effects of the solvent [10, 24-27]. The magnitude of the $\alpha$-effect can be influenced by a number of factors, including the nature of solvent [10, 24-28], the sensitivity of the standard series reactivity ("normal" anionic nucleophiles) to basicity $\left(\beta_{\text {nuc }}\right)[8-20,23]$, type of hybridization of the electrophilic center $[16,24,29,30]$.

As was demonstrated [10, 24-28], the role of the solvent is extremely significant here. Bunsel et al. [24] showed that in nucleophilic substitution reactions involving p-nitrophenyl acetate and related esters, the magnitude of the a-effect strongly depends on the composition of the solvent. The existence of the a-effect in the gas phase was questioned from the beginning $[25,26]$, however, later works [31] made it possible to demonstrate convincingly that the a-effect in the gas phase nevertheless manifests itself.

The $\beta_{\text {nuc }}$ value $[18,20-23]$ and the basicity of the $\alpha$-nucleophile $[1,4,9,10,12,27]$ also affect the magnitude of the a-effect. The a-effect is small or absent for reactions with low values of $\beta_{\text {nuc }}[1-4,9,10-12,27]$ or for reactions involving highly basic $\alpha$-nucleophiles $[27,31]$. 
The type of hybridization of the electrophilic center can play a dominant role in the magnitude of the a-effect. Thus, small (or practically absent) $\alpha$-effect usually occurs for reactions at the $\mathrm{sp}^{3}$-hybridized carbon atom $[24,29]$, while in reactions at the $\mathrm{sp}^{2}$-hybridized carbon atom the reaction rate with participation of $\alpha$-nucleophiles usually increases in 50-100 times [24]. At the same time, the magnitude of the a-effect is extremely high for reactions in the sp-hybridized carbon atom. For example, $\mathrm{HOO}^{-}$ion is $(2-6) \cdot 10^{4}$ times more reactive than, $\mathrm{HO}^{-}$anion with respect to the sp-hybridized carbon atom of benzonitriles in $50 \%$ aqueous ethanol and water $[24,28]$.

The result of the study of the abnormally high reactivity of $\alpha$-nucleophiles was not only the expansion of ideas about the factors influencing the rate of reactions, but also the discovery of a fairly wide field of practical application of these compounds as the basis of formulations for the effective destruction of ecotoxicants $[4,5,7,9,12]$.

\section{Inorganic $\alpha$-nucleophiles - the most effec-} tive class of reagents for the decomposition of organic phosphorus compounds (OPC)

Analysis of data on the reactivity of typical inorganic $\alpha$-nucleophiles in the processes of degradation of acyl-containing substrates [1-7, $9,12-14,34-36]$, including esters of phosphorus acids [4-7, 9, 12-14, 34-36], indicates that inorganic anions $-\mathrm{H}_{2} \mathrm{NO}^{-}, \mathrm{HOO}^{-}, \mathrm{ClO}^{-}, \mathrm{BrO}^{-}$, $\mathrm{HCO}_{4}^{-}, \mathrm{CO}_{4}^{2-}$ - provide abnormally high reaction rates as compared to other supernucleo- philes. A special place among them belongs to hydroperoxide anion, since it is on its basis that highly effective "green" systems can be created for the decomposition of ecotoxicants.

In the considered reaction series, the value of the a-effect for the hydroperoxide ion, defined as the $k_{2}^{\mathrm{HOO}-} / k_{2}^{\mathrm{HO}-}$ ratio, reaches $10 \div 10^{3}$ times, however, it should be even higher, since the acid ionization constant of hydrogen peroxide $(\sim 11,5-11,6[37])$ is approximately 4 units lower than the basicity of $\mathrm{H}_{2} \mathrm{O}(15.74$ [38]), and therefore the nucleophilicity of $\mathrm{HOO}^{-}$(in the absence of the $a$-effect), calculated on the basis of the Brønsted dependence, should be $10^{2}-10^{3}$ times lower than the nucleophilicity of $\mathrm{HO}^{-}$. In this case, the magnitude of the a-effect will be $\sim 10^{5}-10^{6}$ times $^{1}$.

The nature of the ester's acyl group has little effect on the a-effect magnitude of the hydroperoxide ion. In the case of a carbonyl carbon atom, the change in the electrophilicity of the electron-deficient center under the influence of the electronic effects of the acyl group is satisfactorily compensated in the values of

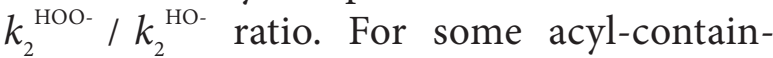
ing substrates such compensation is not observed, but the magnitude of the a-effect is significantly higher. It should be noted that for them, the change in $k_{2}^{\mathrm{HOO}-} / k_{2}^{\mathrm{HO}-}$ ratio is to a greater extent associated with the lower rates of alkaline hydrolysis than would be expected. A detailed study of nucleophilic reactions with the participation of hydroperoxide ion and 4-nitro- and 4-methylbenzoates demonstrated the important role of the nature of the leaving group [33].With fairly easy leaving groups, the $\alpha$-effect is clearly

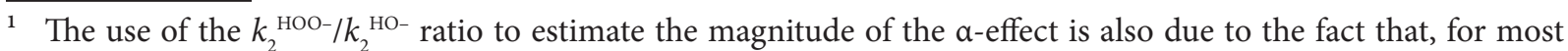
substrates, there are no experimental data for standard reaction series (interaction with arylate and alcoholate ions). 
manifested. With more complicatedly leaving groups it sharply decreases, and in the case of decomposition of 2-fluoroethyl and methyl ethers it has a minimum value. Such a strong dependence of the magnitude of the $\alpha$-effect on the substrate structure was interpreted by the authors of [33] by differences in the position of the transition state on the reaction coordinate in accordance with Hammond's postulate (Fig. 1).

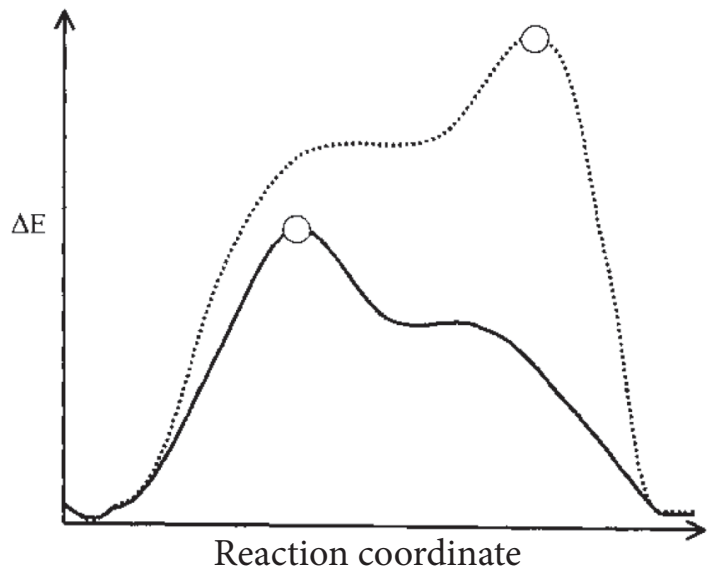

Fig. 1. The energy profile of the interaction of a-nucleophile with substrates containing easily (solid line) and complicatedly (dashed line) leaving groups; $\mathrm{O}$ - speed determining the transition state

Hypohalogenated acids (HHalO) - a unique class of reagents; depending on the acidity of the medium, solutions of these acids contain $\mathrm{HHalO}$, hypohalogenite anion $\left(\mathrm{HalO}^{-}\right.$.) or $\mathrm{HHalO} / \mathrm{HalO}^{-}$. In this case, hypohalogenite ions are typical $\alpha$-nucleophiles $[1-7,9,12,13]$, and their conjugated acids are effective oxidants. The attack of the hypochlorite ion on the electron-deficient centers of the substrates leads to the formation of acylhypohalogenites, which rapidly hydrolyze to the corresponding acids (Fig. 2).

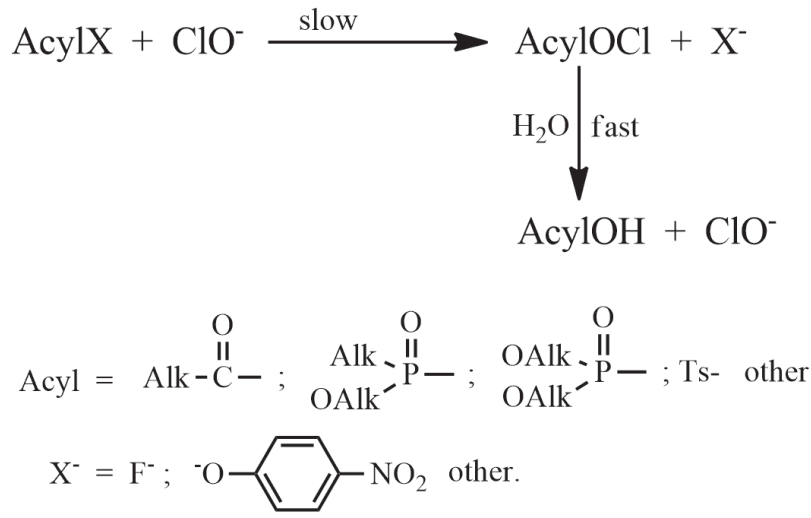

Fig. 2. Reaction of hypochlorite ion with a number of substrates

Consequently, in these reactions $\mathrm{ClO}^{-}$acts as a nucleophilic catalyst [39]. Although the magnitude of the a-effect is less than that for the $\mathrm{HOO}^{-}$ion, nevertheless, taking into account the difference in the basicities of hydroperoxide and hypochlorite ions, which reaches $\sim 10^{4}$ times $\left(\mathrm{pK}_{\mathrm{a}}^{\mathrm{HClO}}=7,2 \div 7,4[12,40]\right)$, hypochlorite ion should be classified as one of the most effective $\alpha$-nucleophiles.

\section{Hydroxylamine, its $\mathrm{N}$-alkyl derivatives, oximes and hydroxamic acids}

Hydroxylamine derivatives have found wide application in various fields of chemistry, including as cleaving agents in the destruction of ecotoxicants and, first of all, organophosphorus compounds $[4,10,12,19,35,43-46]$. The structure of typical representatives of this class of substances is shown in fig. 3 .

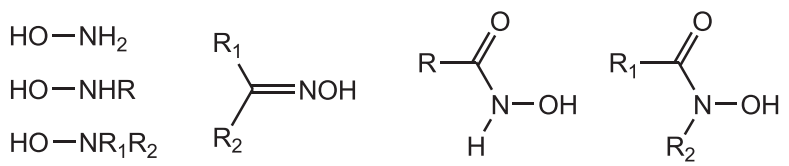

Fig. 3. Hydroxylamine and its $\mathrm{N}$-alkyl derivatives 
An important feature of hydroxylamine, oximes and hydroxamic acids is the presence of a fragment with adjacent $\mathrm{O}$ and $\mathrm{N}$ atoms $(-\mathrm{N}-\mathrm{O}-\mathrm{H})$ containing one or more lone pairs of electrons, which determines their belonging to the class of $\alpha$-nucleophiles $[4,10,12,19,35$, 43-46].

In hydroxylamines (ambident nucleophiles), in nucleophilic substitution reactions at electrophilic centers, both nitrogen and oxygen atoms can act as attacking atoms (left side of fig. 4) [43, 44, 47].

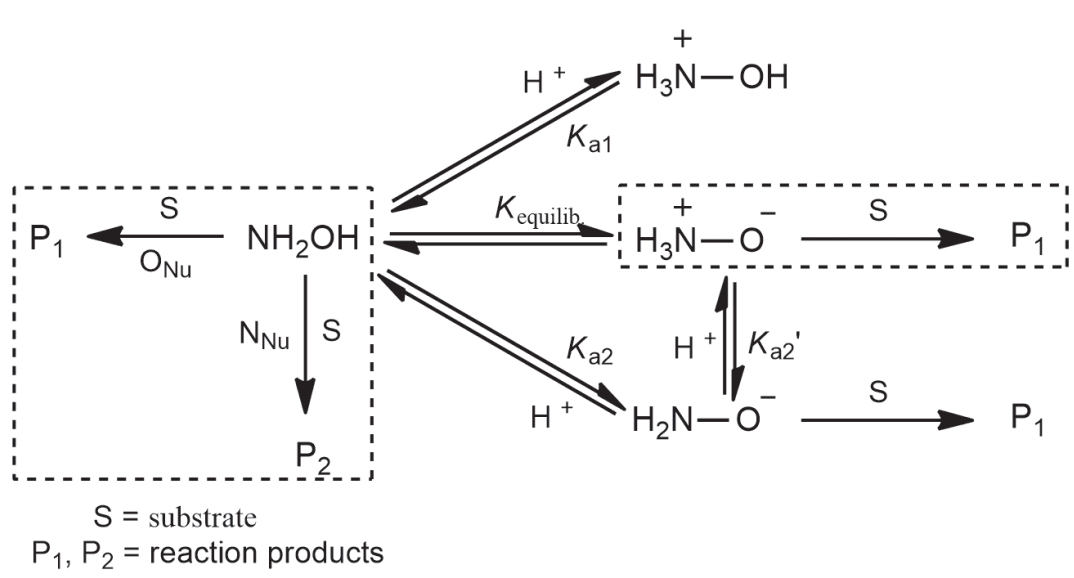

Fig. 4. Scheme of the reactivity of hydroxylamines

In aqueous solutions, depending on the acidity of the medium, hydroxylamine (like its $\mathrm{N}$-alkyl derivatives) can exist in the form of four particles - $\mathrm{NH}_{2} \mathrm{OH},{ }^{+} \mathrm{NH}_{3} \mathrm{O}^{-}, \mathrm{NH}_{2} \mathrm{O}^{-}$and ${ }^{+} \mathrm{NH}_{3} \mathrm{OH}$, the first three of which are potential nucleophilic reagents (fig. 4). Nevertheless, it was considered generally accepted that in reactions involving acid halides and esters of carboxylic, phosphoric and phosphate acids, hydroxylamine interacts with these substrates in the neutral form [48]. However, if we proceed from the definition of the $\alpha$-effect $[1,2]$, the hydroxylamine anion meets all the requirements for $\alpha$-nucleophiles: (i) a nucleophilic center is a negatively charged atom of the second period (an oxygen atom); (ii) there are no substituents near the nucleophilic center that provide steric obstacles to the attack on the electrophilic center of the substrate; (iii) the nucleophile contains a catalytically active group capable of exerting a stabilizing effect on the transition state of the reaction. Finally, in the hydroxylamine molecule there is an electronegative nitrogen atom with a lone pair of electrons in the a-position to the reaction center, which can destabilize the initial state of the reagent and stabilize the transition state of the reaction. Indeed, the authors of [12] were able to demonstrate convincingly that the anionic form of hydroxylamine is responsible for a significant increase in the rate of transfer of the acyl group in alkaline media. This point of view was further confirmed by studies of reactions of bis (2,4-dinitrophenyl)-phosphate [43, 44], 2,4-dinitrophenyl diethyl phosphate with anionic forms of hydroxylamine, $\mathrm{N}$-methylhydroxylamine and N, N-dimethylhydroxylamine, which appeared as typical a-nucleophiles [35].

Even more unusual is the kinetic behavior of the neutral form of hydroxylamine in reactions of acyl group transfer. Points on the corresponding graphs for $\mathrm{NH}_{2} \mathrm{OH}$ in reactions with 4-nitrophenyl ether of diethylphosphoric acid (NPDEP), 4-nitrophenyl ether of diethylphosphonic acid (NPDEPS), 4-nitrophenyl ether of toluene sulfonic acid (NPTS) and p-nitro-phenylacetate (NPA) significantly positively deviate not only from the standard reaction 
series $\left(\Delta=\lg k_{2}^{\mathrm{NH}_{2} \mathrm{OH}}-\lg k_{2}^{\text {нукл. }} \approx 9.0(\mathrm{NPA})\right.$, $\Delta \approx 6.0$ (NPTS), $\Delta \approx 6.0$ (NPDEP), $\Delta \approx 6.1$ (NPDEPS)), but also on the Brønsted dependence for $\alpha$-nucleophiles $(\Delta \approx 3.4$ (NPA), $\Delta \approx$ 1.6 (NPTS), $\Delta \approx 1.6$ (NPDEP) [12]. Obviously, the neutral form of hydroxylamine exhibits an abnormally high reactivity even among inorganic $\alpha$-nucleophiles and reacts with the studied substrates as a hypothetical $\alpha$-nucleophile with $\mathrm{c} p K_{\mathrm{a}} \approx 1-5$.

If we evaluate the value of the $a$-effect of the neutral form of hydroxylamine by the ratio and take into account that the basicity of the oxygen atom in $\mathrm{NH}_{2} \mathrm{OH}$ is unlikely to exceed that for water, then the differences in basicities are $\sim 16$ orders of magnitude, and the a-effect for $\mathrm{NH}_{2} \mathrm{OH}$ is one of the most important among inorganic $\alpha$-nucleophiles.

The data on the reactivity of the neutral form of hydroxylamine indicate that the mechanism of transfer of the acyl group on $\mathrm{NH}_{2} \mathrm{OH}$ is fundamentally different from that for inorganic a-nucleophiles. However, there is still no common point of view on the mechanism of acylation of hydroxylamine. Based on the analysis of kinetic isotope effects, the following mechanism of the reaction of hydroxylamine with NPA was proposed [47]. At the first equilibrium stage, subject to basic assistance from the amino group of hydroxylamine, a tetrahedral intermediate adduct (I) is rapidly formed. Then, at the rate of the determining stage, under the influence of total acidic catalysis, intermediate (I) slowly decomposes with the formation of O-acetylhydroxylamine. The considered mechanism of $\mathrm{O}$-acylation remains controversial, since it cannot explain either the behavior of N, N-dialkylhydroxylamines in this reaction, or the existence of a single Bronsted dependence for the interaction of hydroxylamine and its N-alkyl- and N, N-dialkyl derivatives with NPA. Apparently, the transition states (II - IV) are more preferable in comparison with (I), and a necessary and sufficient condition for this is the participation only of the hydrogen atom of the $\mathrm{OH}$ group of hydroxylamine in the formation of a hydrogen bond [12].

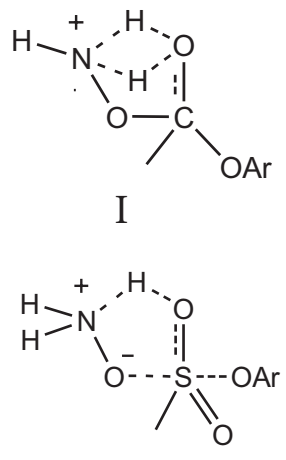

III
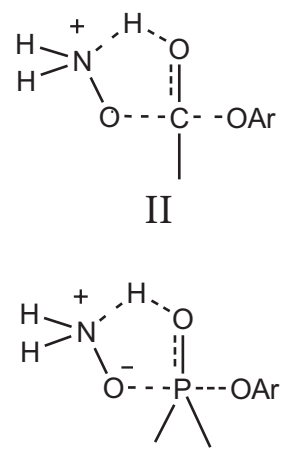

IV
The appearance in the transition states of the anion-like form of hydroxylamine and the presence of a general basic and general acidic assistance should reduce the free energy barrier of the reaction and, therefore, ensure high rates of transfer of the acyl group not only to hydroxylamine, but also to its N-alkyl- and $\mathrm{N}$, $\mathrm{N}$-dialkyl derivatives.

Jencks [40] proposed a different explanation of the O-nucleophilic reactivity of the neutral form of hydroxylamine, based on the possibility of the formation of a bipolar ion $\mathrm{NH}_{3}^{+} \mathrm{O}^{-}$ (Fig. 4). Subsequently, the author considered it unlikely that such particles in sufficient concentrations would be generated in solution [15]. Nevertheless, Kirby et al., based on the formation of products corresponding to the $\mathrm{O}$-attack of electron-deficient centers (phosphorus, carbon), crystallography data, and quantum-chemical calculations, believe that it is $\mathrm{NH}_{3}^{+} \mathrm{O}^{-}$form is responsible for the abnor- 
mally high nucleophilicity of hydroxylamine in neutral media $[35,45,46]$. Nevertheless, at the moment it is hardly possible to consider as strictly proven the formation of $\mathrm{NH}_{3}^{+} \mathrm{O}^{-}--$ ions in aqueous solutions and the supposed reaction mechanism.

In conclusion, it should be noted that hydroxylamine is a unique $\alpha$-nucleophile, and its neutral and anionic forms cause high transfer rates of the acyl group in a wide $\mathrm{pH}$ range, with which none of the known $\alpha$-nucleophiles can compete.

\section{Reactivity of the $\mathrm{HOO}^{-}$anion in the process- es of acyl group transfer}

The anomalously high reactivity of the $\mathrm{HOO}^{-}$anion in the processes of acyl group transfer is usually interpreted from the point of view of the general acid catalysis [38, 40]. Stabilization of the V and VI transition states, due to the formation of a hydrogen bond with the equatorial oxygen atom of the acyl group, will contribute to the rapid elimination of the 4-nitrophenolate ion.
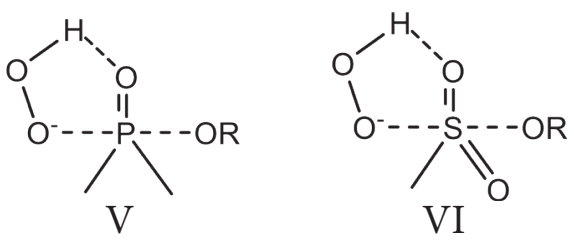

The higher nucleophilicity of the $\mathrm{HOO}^{-}$ion as compared to the $\mathrm{CH}_{3} \mathrm{COO}^{-}$anion in reactions with monoanionic forms of 4-nitrophenyl sulfate $\left.k_{2}^{\mathrm{HOO}^{-}} / k_{2}^{\mathrm{CH}_{3} \mathrm{COO}^{-}} \approx 30\right)$ [34] and 4-nitrophenylmethyl phosphate $\left(k_{2}^{\mathrm{HOO}^{-}} / k_{2}^{\mathrm{CH}_{3} \mathrm{COO}^{-}} \approx 50\right)$ [50], as well as with triacetylethylenediamine $\left.\left(k_{2}^{\mathrm{HOO}^{-}} / k_{2}^{\mathrm{CH}_{3} \mathrm{COO}^{-}}\right) \approx 20\right)[51]$ is consistent with the presence of a hydrogen bond in the transition states of types I and II. However, in reactions with aryl esters of carboxylic acids, the importance of such an interaction is apparently small, since the nucleophilicities of the ions $\mathrm{HOO}^{-}$and $\mathrm{CH}_{3} \mathrm{COO}^{-}$differ only by a factor of $\sim 3$. Therefore, the presence or absence of general acid catalysis is hardly the only factor controlling the supernucleophilic properties of the $\mathrm{HOO}^{-}$ion. Indeed, $\mathrm{HOO}^{-}$ion reacts anomalously quickly with alkyl halides $[2,6,38]$, although this type of catalysis does not play a significant role in the reactions of alkyl group transfer. It is also unlikely that the high rates of acid-catalyzed addition of the $\mathrm{HOO}^{-}$ion to aldehydes are a consequence of the formation of an intramolecular hydrogen bond in these processes [52]. It is possible that an important role in the reactivity of the $\mathrm{HOO}^{-}$ion is played by the stability of the reaction products and the transition state, i.e. the nucleophilicity of the $\mathrm{HOO}^{-}$ion is largely controlled by thermodynamic factors. Apparently, the possibility of implementing intramolecular acid catalysis and the relatively high thermodynamic stability of the transition states are responsible for the observed $\alpha$-effect of the $\mathrm{HOO}^{-}$ion in the transfer of the acyl group.

The manifestation of the $\alpha$-effect in the reactions of hypohalogenite ions with acyl-containing substrates can be explained by the formation of a transition state at the rate of the determining stage, in which there is an interaction of the oxygen of the acyl group with unoccupied d-orbitals of the hypohalogenite ion (VII) [38, 40]. In fact, hypohalogenite ions, being Lewis acids, can provide the same assistance in acyl transfer reactions as Brønsted acids. Nevertheless, as in the case of the hydroperoxide anion, this factor is hardly the only one that provides the a-effect of hypohalogenite ions. 
a

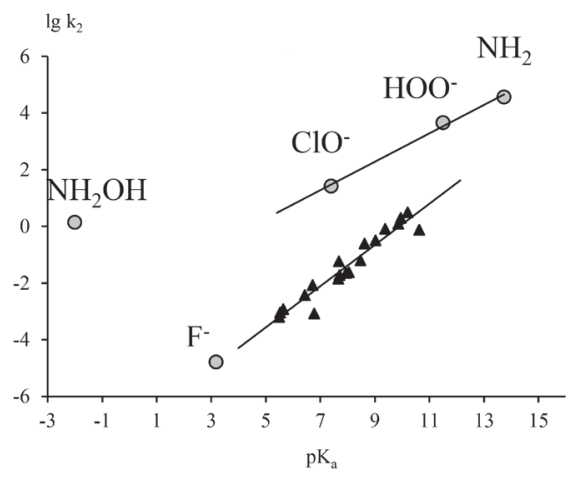

B

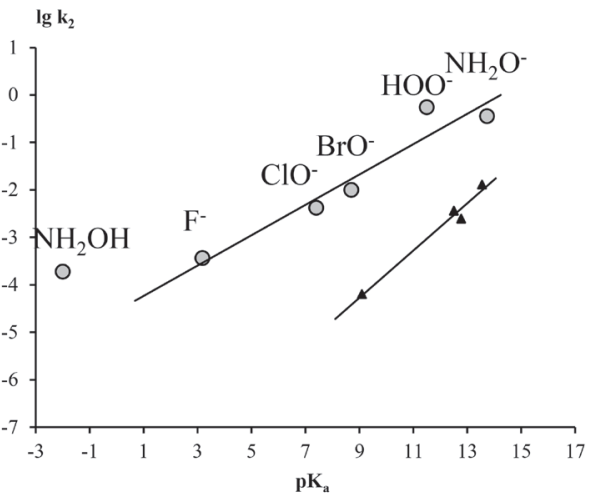

д

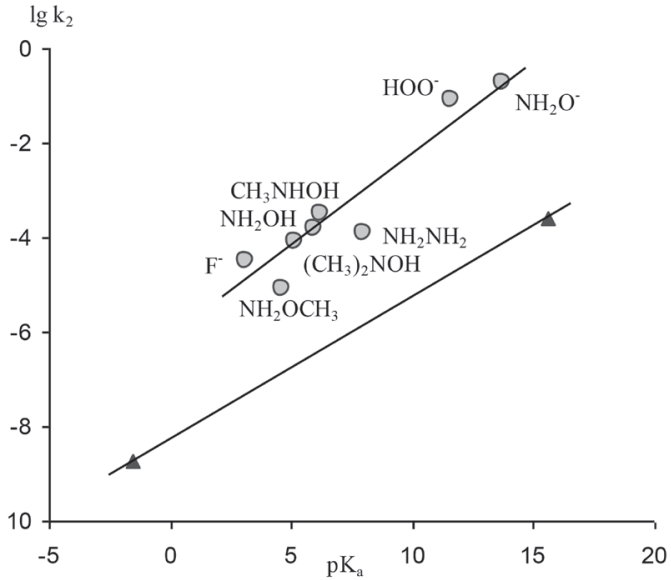

$6 \quad \lg k_{2}$
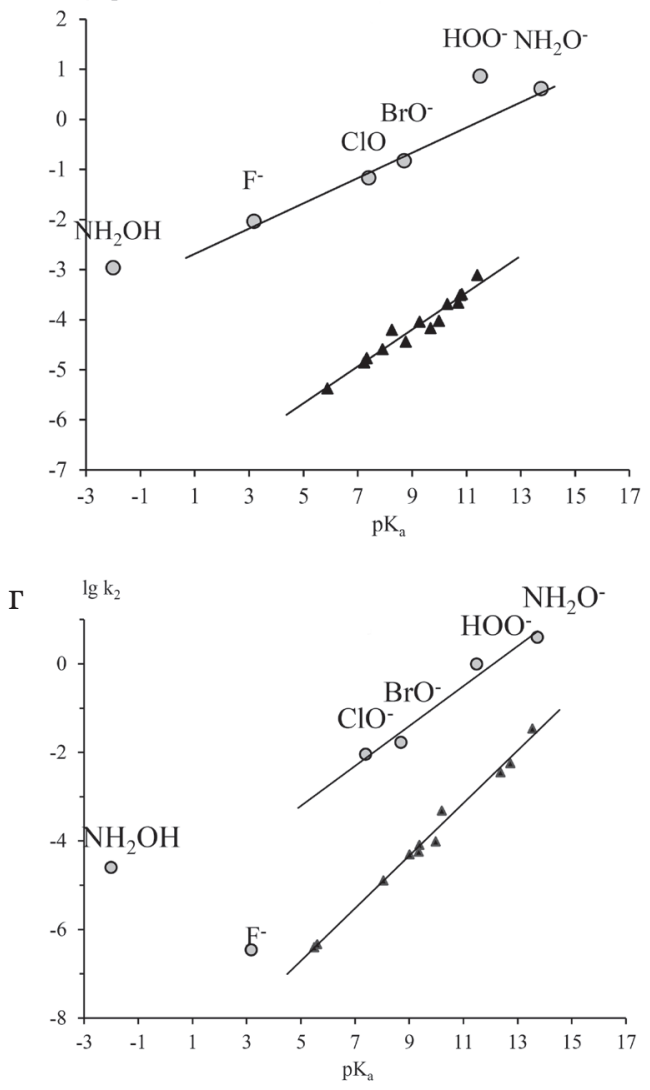

Fig. 5. Brønsted dependences for the reaction of $\alpha$-nucleophiles $(\bullet)$ and arylate ions $(\boldsymbol{\Delta})$ with 4-nitrophenyl acetate (a); 4-nitrophenyl diethyl phosphonate (b); 4-nitrophenyl diethyl phosphate (c); 4-nitrophenyl tosylate (d) [12]; 2,4-dinitrophenyl diethyl phosphate (e) [35] ${ }^{2}$

${ }^{2}$ Attention is drawn to the behavior of the fluorine anion, which, exhibiting an abnormally high affinity for the electron-deficient phosphorus atom, behaves in nucleophilic substitution reactions like an a-nucleophile. One of the possible explanations for this phenomenon is the successful overlap of the orbitals and the high electron-negativity of fluorine, which makes it possible to form a "one and a half" F P bond. 


\section{Reactivity of oximate ions}

The particular interest that has been shown for many years to the study of the nucleophilic reactivity of oxymate ions $\left(\mathrm{Ox}^{-}\right)$is primarily due to the fact that it is among this class of $\alpha$-nucleophiles that effective antidotes have been found - acetylcholinesterase reactivators [10, 53-60], the search for and design of which continues intensively at the present time. There is no doubt that this property of oximate ions is associated with their anomalously high reactivity, and therefore the establishment of the factors controlling the $\alpha$-effect of $\mathrm{Ox}$ - anions is a rather urgent problem.

Extrathermodynamic analysis of the oximate ions behavior in the transfer reactions of aryl sulfonyl, acetyl, phosphoryl and other acyl groups $[10,24,61,62]$ indicates that the solvation effects of water play an important role here. Indeed, the reactivity of typical $\alpha$-nucleophiles - oximate ions cannot be described within the framework of a unified Brønsted equation, and the existence of nonlinear Brønsted dependences (Fig. 6) for the transfer of acyl groups is a consequence of energetically unfavorable effects of solvent $[10,24,61,62]$.

Analysis of the Brønsted dependences for reactions of oximate ions and standard reaction series (arylate and alcoholate ions) [10, $24,61,62]$ makes it possible to establish regularities in the nature of the change in the $k_{2}$ and $\alpha$-effect values at varying the structure of the oxime. First, $\mathrm{Ox}^{-}$ions in acyl group transfer reactions act as typical $\alpha$-nucleophiles, and the magnitude of the $\alpha$-effect, defined as the $k_{2}^{\mathrm{Ox}^{-}} / k_{2}^{\mathrm{ArO}^{-}\left(\mathrm{RO}^{-}\right)}$ratio at $\mathrm{p} K_{\mathrm{a}}^{\mathrm{Ox}^{-}} \approx \mathrm{p} K_{\mathrm{a}}^{\mathrm{ArO}^{-}\left(\mathrm{RO}^{-}\right)}$, significantly depends on the oxime structure. As the acidity of the oxime decreases $(\leq 9.0)$, the $\alpha$-effect, within the reaction series, persists at $\sim 10^{2}-10^{3}$ times. Although a further increase in the oxime basicity $(\geq 9.0)$ leads to a slight increase in the $k_{2}^{\text {Ox- }}$ values, the value of the a-effect begins to decrease in this case (Fig. 6). And, finally, oxymate ions with $\mathrm{p} K_{\mathrm{a}}^{\mathrm{Ox}^{-}} \geq 12.0$ in terms of reactivity no longer exceed high-basic alcoholate ions $\left(k_{2}^{\mathrm{Ox}^{-}} / k_{2}^{\mathrm{RO}^{-}} \approx 1.0\right)$, i.e. the a effect disappears. Moreover, they form one Brønsted dependence with highly basic alcoholate ions, i.e. for all substrates, regardless of the nature of the electrophilic center, the limiting reactivity of $\mathrm{Ox}^{-}$ions in water is comparable to that for highly basic alcoholate ions $[63,64]$. Particularly noteworthy is the effect of "leveling" the reactivity of $\mathrm{Ox}^{-}$ions, noted already $\mathrm{p} K_{\mathrm{a}}^{\mathrm{Ox}} \geq 9.0$, leading to a decrease in the value of the $a$-effect with an increase in the basicity of the oxime and, finally, to its disappearance (at $\mathrm{p} K_{\mathrm{a}}^{\mathrm{Ox}} \geq 12.0$ ). Secondly, for processes with the participation of $\mathrm{Ox}^{-}$ions, an extremely early break in the Brønsted dependence is observed, which occurs at $\mathrm{p} K_{\mathrm{a}} \approx 8.0-9.0$, while for arylate and alcoholate ions it occurs in the region of $\mathrm{p} K_{\mathrm{a}} \approx 12.5-13.0[6$

The curvature of the Brønsted dependence for the reactions of anionic nucleophiles arylate, alcoholate, oximate ions, etc. [10, 24, 61-67] with substrates containing electron-deficient centers of carbon, sulfur and phosphorus, can be associated not only with the energetically unfavorable solvation effects of the solvent, the contribution of which becomes more and more significant as the basicity of the nucleophile increases [63, 65-67], but also with a change in the structure of the transition state. Nevertheless, it is unlikely that for the reaction series under consideration, with an increase in the basicity of $\mathrm{Ox}^{-}$ions, such a strong change in the structure of the transition state occurs. So, for example, for the reactions of NPA, 

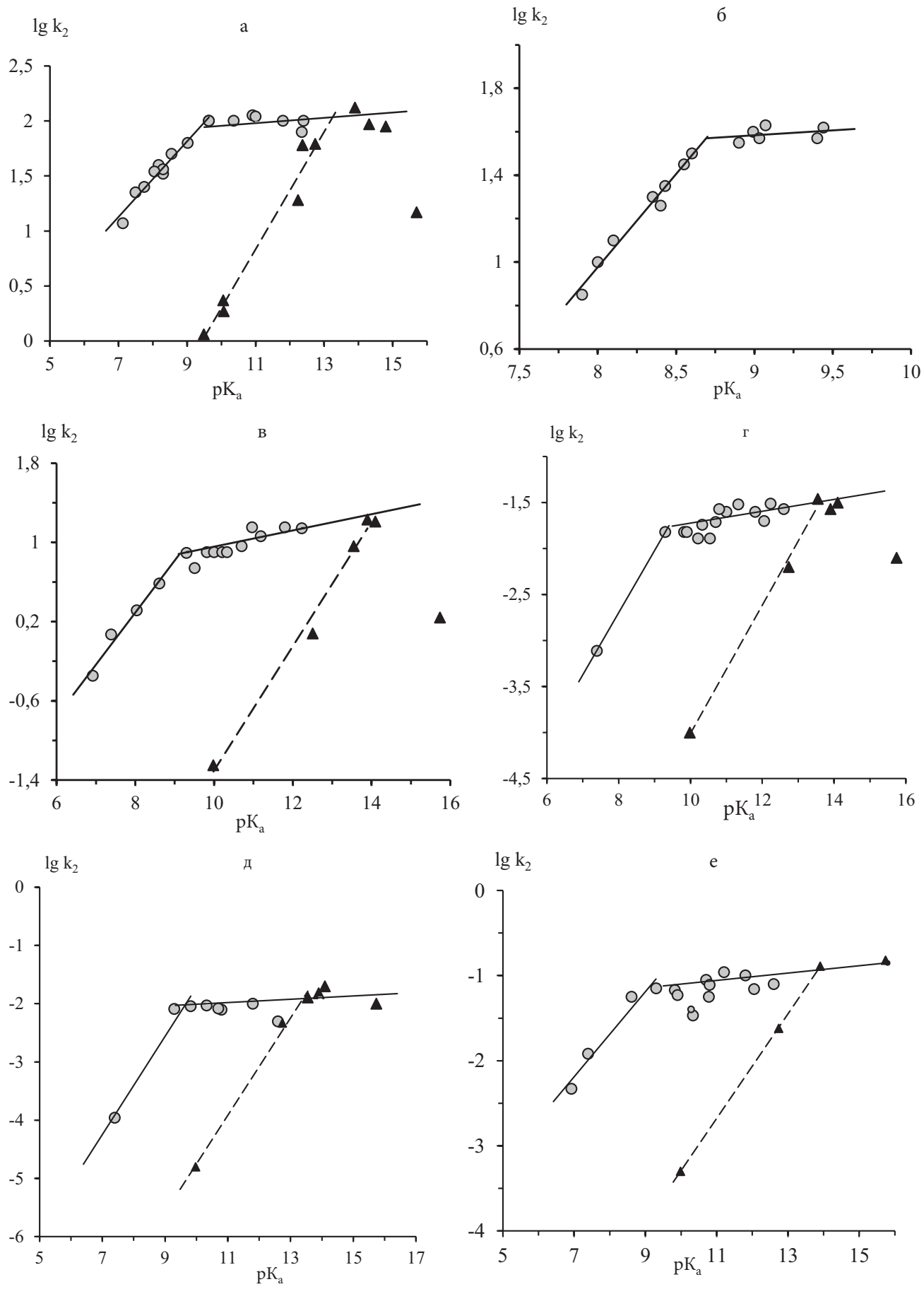

Fig. 6. Brønsted dependences for the reaction of oximate- $(\bullet)$ and arylate-(alcoholate-) ions $(\boldsymbol{\Delta})$ with 4-nitrophenyl acetate (a), diisopropyl fluorophosphate (b), 2,4-dinitrophenyltosylate (c), 4-nitrophenyltosylate (d), 4-nitrophenyl diethyl phosphate (e), 4-nitrophenyl diethyl phosphonate (f) [61, 62]. 
DNPTS, NPTS, NPDEP and NPDEPS with oximate ions, regardless of the nature of the electron-deficient center of the substrate and the leaving group, the sensitivity of the reactivity of a series of $\alpha$-nucleophiles (in this case oximes) to basicity $\left(\beta_{\mathrm{N}}\right)$ varies from $0.5-0.6$ $\left(\mathrm{p} K_{\mathrm{a}}^{\text {Ox }} \leq 9.0\right)$ to $0.1-0.2\left(\mathrm{p} K_{\mathrm{a}}^{\text {Ox }} \geq 9.0\right)$, despite the fact that the maximum difference in reactivity when passing from NPA to NPDEP is $10^{5}$ times. In addition, a break in the correlation dependences occurs at $\mathrm{p} K_{\mathrm{a}} \approx 8.0-9.0$, and its position is practically independent of the structure and reactivity of the substrate. This once again confirms that the nonlinear Brønsted dependences for reactions with $\mathrm{Ox}^{-}$ions reflect rather the differences in the nature of the solvation states of low-basic and high-basic oximate ions in water, as it is interpreted for the reactions of the transfer of the acyl group to arylate and alcoholate ions [63-66], as well as to neutral and anionic nitrogen-containing reagents [67].

\section{Inorganic $\alpha$-nucleophiles - the basis of formulations for the degradation of neurotoxins, vesicants and organophosphorus pesticides}

mechanism of reactions with the participation of $\alpha$-nucleophiles and the design of recipes based on them have been carried out for chemical warfare agents [68-71].

In an alkaline medium, organic substances, such as sarin (GB), are rapidly destroyed due to the nucleophilic attack of the hydroperoxide ion on the phosphorus atom with the formation of peroxy acids, which quickly decompose to the corresponding phosphonic acid (Fig. 7) $[5,69-71]$.

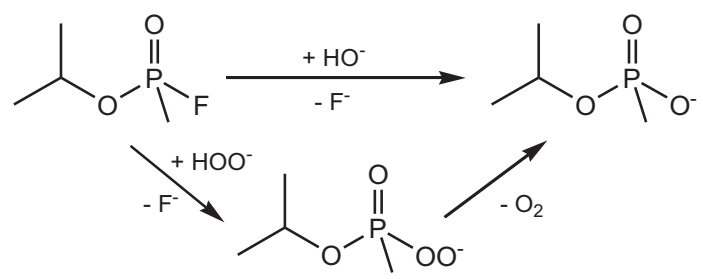

Fig. 7. Scheme of GB degassing in an alkaline medium by hydroperoxide ion

In this case, the reaction rate is $\sim 50$ times higher than the rate of alkaline hydrolysis [32].

VX peroxyhydrolysis proceeds according to the scheme in Fig. 8, with the formation of ethylmethylphosphonic acid. N-oxide of VX is another reaction product, which later, in a slower stage, undergoes a nucleophilic attack with the formation of an acid. In this case, the released thiol undergoes oxidation to sulfonate [5].

Inorganic $\alpha$-nucleophiles - HOO- and $\mathrm{ClO}-$ ions, exhibiting anomalously high reactivity, are of interest as the basis of formulations for the decomposition of ecotoxicants. For quite understandable reasons, detailed studies of the

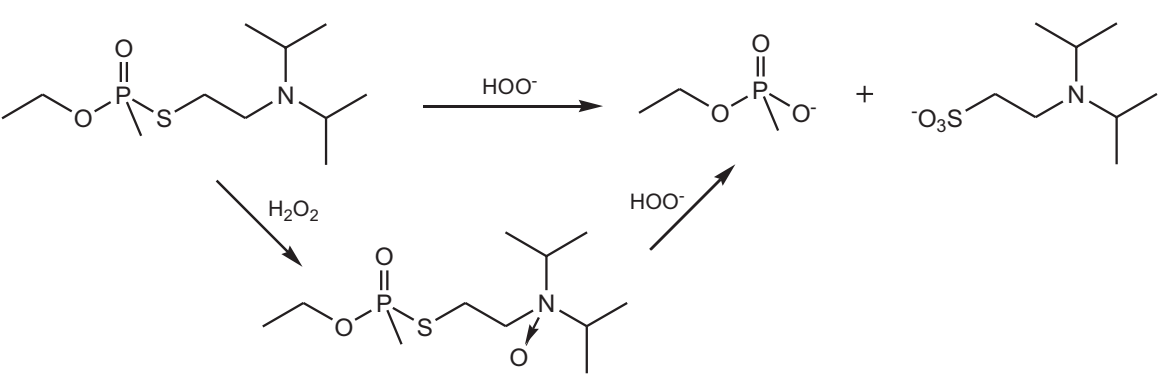

Fig. 8. Scheme of VX degassing with peroxyhydroxide ion 
The reaction of $\mathrm{VX}$ with $\mathrm{HOO}^{-}$anion proceeds approximately 40 times faster than with the more basic $\mathrm{HO}^{-}$ion $\left(\left(\tau_{1 / 2}=45 \mathrm{~s}, 23^{\circ} \mathrm{C}\right.\right.$, $\left.\left[\mathrm{HOO}^{-}\right]=0.1 \mathrm{M}\right)$, which allows to carry out effectively the destruction of VX in alkaline medium by the nucleophilic mechanism. In neutral and acidic media, concentrated solutions of hydrogen peroxide, exhibiting oxidizing properties under these conditions, oxidize mustard gas and $\mathrm{V}$-gases. Since $\mathrm{p}_{\mathrm{a}}^{\mathrm{H}_{2} \mathrm{O}_{2}}=11.5-11.6$, then to ensure the decomposition of ecotoxicants by both the nucleophilic and oxidative mechanisms, the $\mathrm{pH}$ of the medium will be of great importance (and the optimal conditions for carrying out these reactions are different), and, therefore, hydrogen peroxide is hardly can be considered a universal degassing substance. Nevertheless, intensive studies of the reactivity of hydrogen peroxide and its activators (carbonates, molybdates, phthalates, etc.) have led to the creation of universal formulations of the nucleophilic-oxidative mechanism of action, which are quite effective in relation to the main types of organic substances [72, 73 ]. Thus, the activation of $\mathrm{H}_{2} \mathrm{O}_{2}$ by sodium bicarbonate leads to the appearance in the reaction mixture in weakly alkaline media of $\mathrm{HCO}_{4}^{-}$anion, which is a more powerful oxidizing agent than $\mathrm{H}_{2} \mathrm{O}_{2}$, and this makes it possible to destroy toxical agents not only of the GB and VX type, but also HD (Fig. 9).

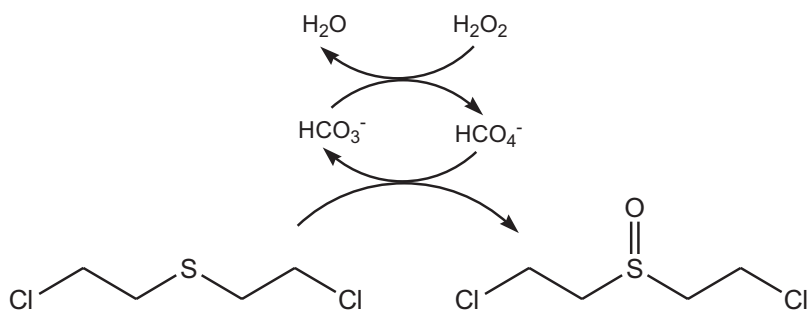

Fig. 9. Scheme of $\mathrm{HD}$ degassing using $\mathrm{HCO}^{-}$anion
The use of potassium molybdate as an activator of hydrogen peroxide in microemulsions of the oil/water type makes it possible to design universal systems for the destruction of ecotoxicants of various nature [73]. The advantage of this system is that the oxidation of $\mathrm{HD}$ mainly leads to the formation of sulfoxide (HDO) rather than the highly toxic sulfone $\left(\mathrm{HDO}_{2}\right)$ [73].

Chloric acid salts are widely used in the decomposition of ecotoxicants [5]. Hypochlorites are universal degassing substances and are used to detoxify human skin, equipment, and territory [5]. In reactions of nucleophilic substitution at the tetracoordinated atom of phosphorus, the $\mathrm{ClO}^{-}$ion acts as a true nucleophilic catalyst and decomposes the GB type of subtanses to phosphonic acids (Fig. 10).

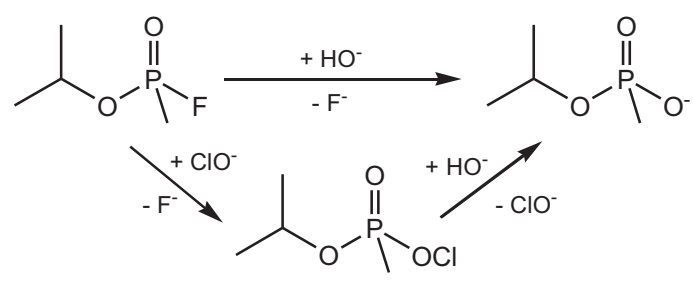

Fig. 10. Scheme of GB degassing using hypochlorite anion

The high oxidative activity of hypochlorous acid plays an important role in the degassing of mustard gas, which in alkaline media undergoes destruction with the formation of a number of oxidation and elimination products (Fig. 11). It should be emphasized that at the first stage of this rather complex process, sulfoxide is formed, which is subsequently converted into other products. 


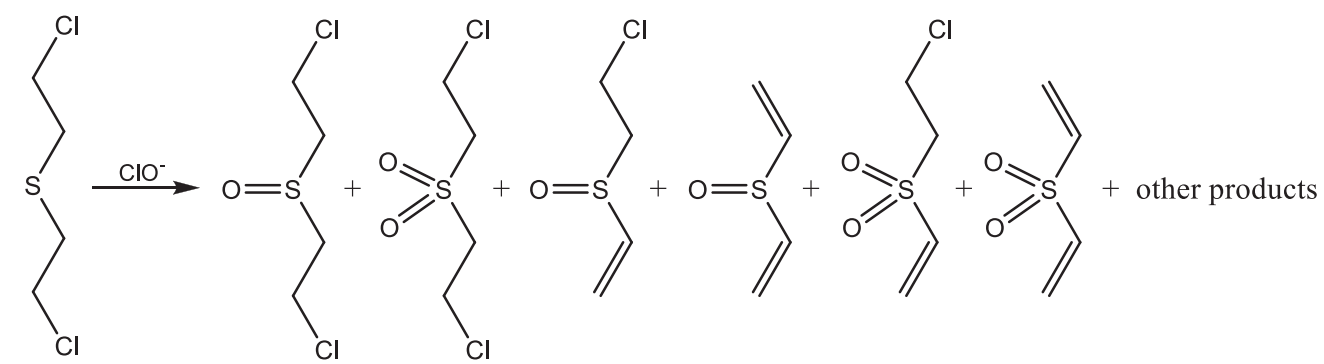

Fig. 11. Scheme of mustard gas degassing using hypochlorite anion

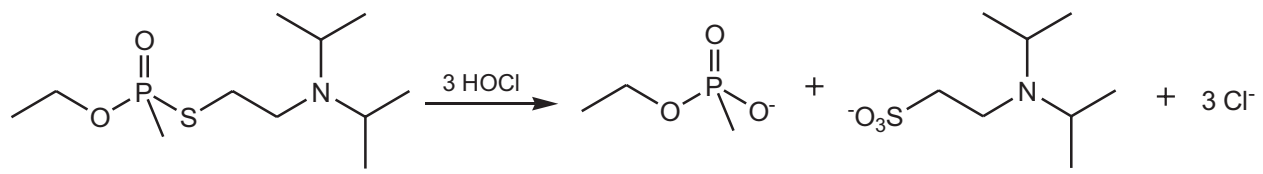

Fig. 12. VX degassing scheme using hypochlorite anion

Hypochlorite solutions can also be used for degassing of $\mathrm{VX}$, especially in the low $\mathrm{pH}$ range (Fig. 12). In this case, for the destruction of 1 mole of VX, only 3 moles of "active" chlorine are consumed. For the oxidation of 1 mole of VX in alkaline media, more than 10 moles of "active" chlorine are required.

Despite the fact that hypochlorites are produced on a large scale and are relatively inexpensive, they, as degassing substances, have a number of significant disadvantages: 1) low stability during storage; 2) strong corrosive action on the surface during storage and use; 3) relatively high toxicity, etc. Softer agents for degassing of organic matter are $\mathrm{N}-\mathrm{Cl}$ derivatives of ammonia, amines, amides, ureas, hydantoins, urethanes, etc. [5], the so-called chloramines, which can be considered as derivatives of perchloric acid amide ( $\mathrm{HClO}$ and $\mathrm{R}\left(\mathrm{R}^{\prime}\right) \mathrm{N}-\mathrm{Cl}$ ). However, these compounds are not devoid of certain disadvantages: 1) lack of universality of action; 2) weaker action at low temperatures; 3 ) high consumption of solvents for non-water-soluble reagents, etc.
A brief analysis of data on the use of inorganic a-nucleophiles as the basis of formulations for the breakdown of ecotoxicants allows us to draw an important conclusion: the use of "green" systems hydrogen peroxide - activator for the destruction of toxic substrates on an industrial scale and treatment of surfaces of considerable area is undoubtedly more preferable than systems containing "active" chlorine, since the former are not toxic, are not corrosive and do not pose a threat to the environment. As for minimizing the consequences of emergency situations and terrorist acts associated with the spill of toxic agents, the most expedient is the use of systems based on "active" halogen. These have an extremely successful combination of oxidizing and nucleophilic properties, allowing their use not only for the destruction of substrates of various chemical natures, but also for the destruction of dangerous biological objects (pathogenic bacteria and viruses), i.e. using the same system to solve the problems of chemical and biological protection. 


\section{Design of inhibited acetylcholinesterase re- activators based on hydroxylamine derivatives}

The fact that some phosphate esters have insecticidal properties (found at the beginning of the twentieth century) opened up broad prospects for the use of this class of compounds and a number of their analogs in agriculture to control insect pests $[75,76]$. The high toxicity in relation to mammals, which was discovered somewhat later for many of these substances, not only made it necessary to take a more careful approach to the selection of compounds recommended for practical use, but also made it possible to create a new generation of chemical weapons - neuroparalytic chemical warfare agents $[77,78]$.

A detailed study of the nature of the biological activity of organophosphorus substances of this group showed that all of them are inhibitors of acetylcholinesterase (AChE), an enzyme that plays a key role in the transmission of neuronal signalings [75-78]. Inactivation of AChE by these compounds occurs due to acylation of the HO-group of serine in the active center of the enzyme [77, 78].

When searching for antidotes for these acetylcholinesterase inhibitors, oxymates, as well as hydroxylamines and hydroxamates, have become of paramount importance, since under mild conditions they can remove the acetyl group from the active center of the enzyme and thereby restore its activity $[10,55$, $77,78]$.
Modeling the process of oxime-induced reactivation inhibited by the organophosphorus compound AChE using the Density Functional Theory (DFT) approach [10, 54] showed that of the two possible reactivation pathways (A and B) shown in Fig. 13, preference should be given to a two-stage mechanism (B): 


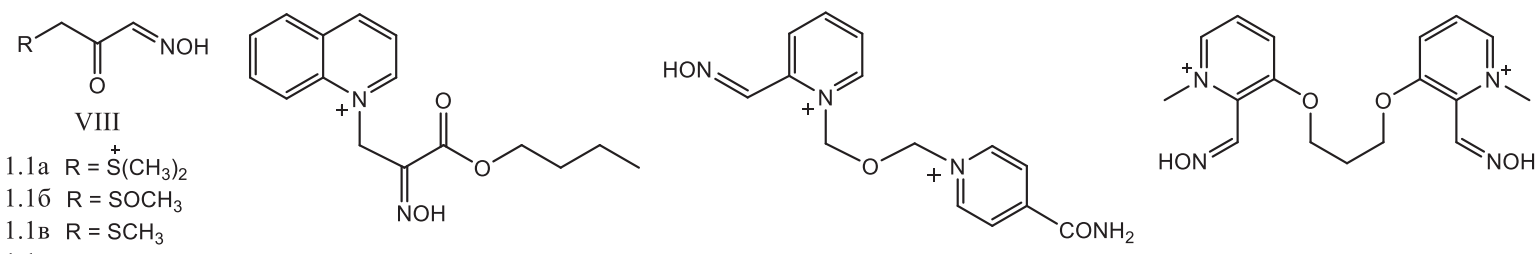

$1.1 \Gamma \mathrm{R}=\mathrm{H}(\mathrm{MINA})$

$1.1 \mathrm{I} \mathrm{R}=\mathrm{SO}_{2} \mathrm{CH}_{3}$

IX (R744)

$\mathrm{X}(\mathrm{HI})$

XI (R665)<smiles>[X]C[n+]1ccc(C=NO)cc1</smiles>

XII $\mathrm{X}=\mathrm{O}$ (Токсогонин)

XIII $\mathrm{X}=\mathrm{CH}_{2}(\mathrm{TMB} 4)$
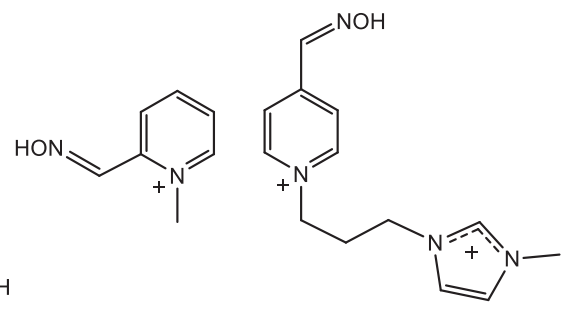

XV (CEB1574)<smiles>C[n+]1ccc(C=NO)cc1</smiles>

XVI (4-PAM)<smiles>O=Cc1ccccc1O</smiles><smiles>CC(=O)C(C)=NO</smiles>

XVIII<smiles>[X][M]O[W]</smiles>

Fig. 14. Structures of the most commonly used antidotes VIII - XXV.

A similar series of reactivators of inhibited (BNPMP), 4-nitrophenyl phosphonate NPP), AChE, which has some advantage over pyrid- fenitrothion, etc.). [53-62, 80-88]. inium derivatives, contains a diazolyl ring XXVI - XXIX [80].<smiles>[R]C(=[NH2+])c1[X]c([R])[nH]n1</smiles>

XXVI $\mathrm{X}=\mathrm{O}$

XXVII $\mathrm{X}=\mathrm{s}$<smiles>[R]C(=NO)c1n[nH]c([R])n1</smiles>

XXVIII $X=0$

XXIX $\quad X=S$

The literature contains data on the reactivity of oximates with respect to various organophosphorus compounds, such as phosphinates, phosphonates, phosphates and their thioanalogues (4-nitrophenyl diphenylphosphinate (NPDPP), bis-nitrophenyl methylphosphonate

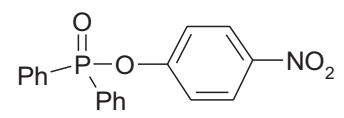

BNPMP<smiles>CP(=O)(Oc1ccc([N+](=O)[O-])cc1)Oc1ccc([N+](=O)[O-])cc1</smiles>

NPDPP<smiles>O=[N+]([O-])c1ccc(OP(=O)(O)O)cc1</smiles>

NPP<smiles>COP(=S)(OC)Oc1ccc([N+](=O)[O-])c(C)c1</smiles> 
At the moment, the reactivators of inhibited AChE (in combination with anticholinergics) recommended for use make it possible to neutralize the effect of at least two lethal doses of neuro paralytic agent [77-79]. Compounds VIII - XXV and a number of their structural analogs eliminate the symptoms of acute poisoning, however, the level of their activity does not allow us to consider the problem of searching for new, more efficient reactivators as solved $[55,56$, $61,77]$. Experiments carried out on animals and humans have shown that in a number of cases using VIII - XXV it is not enough to restore the required level of enzyme activity, and this leads to the development of undesirable consequences in the coming months after poisoning [77, 89-93]. That is why the problem of searching for new AChE reactivators remains in the center of attention and, undoubtedly, the works aimed at solving it are urgent [53-61;92;93].

\section{Ways of structural modification of $\alpha$-nu- cleophiles and systems based on them}

The fulfillment of the Brønsted dependences for the reactions of inorganic $\alpha$-nucleophiles with electron-deficient substrates (eq. 1-6) [12] indicates that the basicity of the a-nucleophile can serve as a characteristic on the basis of which it is possible to predict the reactivity new $a$-nucleophilic reagents

$$
\begin{aligned}
& \lg k_{2}{ }^{\text {NPA }}=-2.2+0.5 p K_{a} \\
& \lg k_{2}^{\text {NPTS }}=-5.5+0.45 p K_{a} \\
& \lg k_{2}^{\text {NPDMC }}=-7.2+0.46 p K_{a} \\
& \lg k_{2}^{\text {NPDEP }}=-4.4+0.28 p K_{a} \\
& \lg k_{2}^{\text {NPDEP }}=-2.9+0.25 p K_{a} \\
& \lg k_{2}^{\text {DNEP }}=-6.1+0.41 p K_{a}
\end{aligned}
$$

Another important conclusion following from the analysis of the Brønsted dependences: the $\mathrm{NH}_{2} \mathrm{O}^{-}$anion is the most powerful acceptor of the acyl group in the series of $\alpha$-nucleophiles. Since $\mathrm{p} K_{\mathrm{a}}^{\mathrm{NH}_{2} \mathrm{O}^{-}} \approx 13.8$ [12], it is difficult to imagine the structure of a-nucleophile, which in water has a basicity comparable to or higher than the hydroxylamine anion. Therefore, based on the basicity of the $\mathrm{NH}_{2} \mathrm{O}^{-}$anion, it is possible to postulate the value of the limiting reactivity of inorganic a-nucleophiles in each reaction series. Nevertheless, this fact does not mean that the design of new a-nucleophiles or their structural modification is not an urgent problem. The focus of researchers is on the designing nucleophilic or universal systems that are not only highly efficient in the decomposition of ecotoxicants, but also have sufficient stability during storage, are safe for storage, do not pose a threat to the environment and etc. The main ways to solve this problem are as follows:

1. Search for new activators of hydrogen peroxide. The use of $\mathrm{H}_{2} \mathrm{O}_{2}$ activators, leading to the generation of new nucleophilic and oxidizing particles in the reaction system, allows fast and irreversible splitting of eco-toxicants of various chemical nature under milder conditions.

2. Creation of new sources of "active" halogen. It seems promising in this direction to obtain organocomplexes of tribromide ion [4], the use of which should ensure overcoming a number of disadvantages inherent in existing systems based on "active" chlorine [5].

3. Obtaining low-basic oximes. As discussed above, understanding the reaction mechanism with the participation of oximate ions and the patterns in their reactivity change makes it possible to explain the nonlinear form of the Brønsted dependence. 
The Brønsted dependences for the reactions of oximate and arylate ions with organophosphorus organic substances - sarin, soman, and diisopropyl fluorophosphate - have a charactferistic feature: the reactivity of oximate ions at $\mathrm{p} K_{\mathrm{a}}^{\mathrm{Ox}^{-}} \geq 8.5$ is straightening [61]. The same kind of dependences was established earlier for other acyl-containing substrates [12]. Obviously, the observed "saturation" effect, in the case of organophosphorus poisonous substances, is of great practical importance since the detoxification process will be effective both when using highly basic and relatively weakly basic oximate ions. This factor determines the ways of scientifically grounded modification of the structure of oximes.

\section{РЕАКЦИЙНА ЗДАТНІСТЬ НУКЛЕОФІЛІВ I ๙-ЕФЕКТ У ПРОЦЕСАХ ЗАМІЩЕННЯ} В ЕЛЕКТРОНОДЕФЦИТНИХ ЦЕНТРАХ

\section{А. Ф. Попов ${ }^{1}$, I. В. Капітанов ${ }^{1,3}$,} Г. О. Сердюк $\kappa^{1,3}$, О. Є. Шумейко ${ }^{1,2^{*}}$

${ }^{1}$ Інститут фізико-органічної хімії і вуглехімії ім. Л. М. Литвиненка НАН України; вул. Харківське шосе 50, Київ 02160, Україна

${ }^{2}$ Інститут органічної хімії НАН України; вул. Мурманська 5, Київ 02660, Україна

${ }^{3} Ц$ ентр передового досвіду в галузі зеленої хімії Європейського дослідницького простору, відділення хімії та біотехнології, факультет наук, Талліннський технічний університет, Академія, 15, Таллінн, 12618, Естонія

*E-mail:ashumeiko@ukr.net
В огляді проаналізовано питання, пов'язані з реактивністю нуклеофілів та проявом а-ефекту в процесах заміщення в електронедефіцитних центрах. Обговорено фундаментальні аспекти цього явища, а також можливості та перспективи використання -н-нуклеофілів у системах для високоефективної деградації субстратів- екотоксикантів різної природи. У першій частині огляду було розглянуто такі аспекти: неорганічні $\alpha$-нуклеофіли як найефективніший клас реагентів для розкладання органічних сполук фосфору, гідроксиламіну, його $\mathrm{N}$-алкільних похідних, оксимів та гідроксамових кислот, реактивність НОО-аніона в процеcax перенесення ацильної групи, реакційної здатності оксиматних іонів, неорганічних $\alpha$-нуклеофілів як основи рецептур для деградації нейротоксинів, везикантів та органофосфорних пестицидів, проектування інгібіторних реактиваторів ацетилхолінестерази на основі похідних гідроксиламіну, способів структурної модифікації a-нуклеофіли та системи на їхній основі. Проаналізовано дані про реакційну здатність типових неорганічних $\alpha$-нуклеофілів при розщепленні ацилвмісних субстратів, включаючи складні ефіри фосфорної кислоти, які забезпечують аномально високі швидкості реакції порівняно з іншими наднуклеофілами. Розглянуто різні типи таких a-нуклеофілів, особливості їхньої структури та реакційної здатності. Було показано, що важливою особливістю гідроксиламіну, оксимів та гідроксамових кислот $є$ наявність фрагмента з сусідніми атомами О та $\mathrm{N}(-\mathrm{N}-\mathrm{O}-\mathrm{H})$, що містять одну чи більше парних електронних пар, що визначає їхню належність до класу $а$-нуклеофілів. Показано, що за прояв $\alpha$-ефекту та його величини 
може бути відповідальною низка факторів, головний з яких дестабілізується основним станом нуклеофіла за рахунок відштовхування самотніх пар електронів, стабілізації перехідного стану, незвичайної термодинамічної стійкості продуктів реакції, сольватаційних ефектів розчинника, типу гібридизації електрофільного центру тощо.

Ключові слова: функціоналізовані ПАР, а-нуклеофіли, міцелярні системи, гідроксиламін, оксими, амідоксими, гідроксамові кислоти, пероксиди,

\section{РЕАКЦИОННАЯ СПОСОБНОСТЬ}

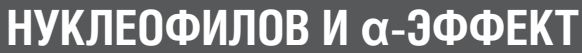
В ПРОЦЕССАХ ЗАМЕЩЕНИЯ У ЭЛЕКТРОНОДЕФИЦИТНЫХ ЦЕНТРОВ

А. Ф. Попов ${ }^{1}$, И. В. Капитанов ${ }^{1,3}$, А. А. Сердюк ${ }^{1,3}$, А. Е. Шумейко ${ }^{1,2}$ *

${ }^{1}$ Институт физико-органической химии и углехимии им. Л. М. Литвиненко НАН Украины; ул. Харьковское шоссе 50, Киев 02160, Украина

${ }^{2}$ Институт органической химии НАН Украины; ул. Мурманская 5, Киев 02660, Украина

${ }^{3}$ Центр передового опыта в области зеленой химии Европейского исследовательского пространства, Отделение химии и биотехнологии, факультет наук, Таллиннский технический университет, Академия, 15, Таллинн, 12618 , Эстония

*E-mail: ashumeiko@ukr.net
В обзоре проанализированы вопросы, связанные с реакционной способностью нуклеофилов и проявлением а-эффекта в процессах замещения у электронодефицитных центров. Обсуждены фундаментальные аспекты этого явления, а также возможности и перспективы использования $\alpha$-нуклеофилов в системах для высокоэффективного расщепления субстратов-экотоксикантов различной природы.

Ключевые слова: функционализированные ПАВ, $а$-нуклеофилы, мицеллярные системы, гидроксиламин, оксимы, амидоксимы, гидроксамовые кислоты, пероксиды.

\section{ЛИТЕРАТУРА}

1. John O., Edwards R., Pearson G. The Factors Determining Nucleophilic Reactivities // J. Am. Chem. Soc. - 1962. - 84, № 1. - P. 16-24.

2. Nick J., John O. Edwards R. The Alpha Effect. Review // International J. Chem. kinetics. 1973. - 5. - P. 1-26.

3. Попов А., Савелова В.Современныеподходы к конструированию высокоэффективных нуклеофильных систем // Теорет. и эксперим. химия. - 1999. - 35, № 1. -С. 1-16.

4. Popov A. Design of green microorganized systems for decontamination of ecotoxicants // Pure Appl. Chem. -2008. - 80, № 7. - P. 13811397.

5. Decontamination of Chemical Warfare Agents / Yu-Chu Y., James A., Baker J. Ward R. // Chem. Rev. - 1992. - 92, № 8. - P. 1729-1743.

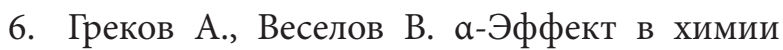
органических соединений // Успехи химии. - 1978. - 47, №.7. - С.1200-1230. 
7. Décontamination chimique. I. Déphosphorylation des composés organophosphorés / Séguès B., Pérez E., Rico-Lattes I., Rivière M., Lattes A. // Bull. Soc. Chim. Fr. -1996. - 133. - P. 925-937.

8. Применение организованных молекулярных систем для химического разложения боевых отравляющих веществ / А. Латт, И. Рико-Латт, Є. Перез, В. Крутиков, Б. Амада // Журн. Рос. хим. об-ва им. Д. И. Менделеева. - 2007. - 51, № 6. - С. 36-43.

9. Реакционная способность неорганических а-нуклеофилов в процессах переноса фосфорильной и фосфонильной групп / А. Попов, Т. Прокопьева, И. Супрун, Ю. Симаненко // Теорет. и эксперим. химия. - 2000. 36, № 4. - C. 226-232.

10. Rappoport E., Liebmann J. The chemistry of Hydroxylamines, Oximes and Hydroxamic Acids. - England: John Wiley \& Sons Ltd., 2009.

11. Morales-Rojas H., Moss R. Phosphorolytic Reactivity of o-Iodosylcarboxylates and Related Nucleophiles // Chem. Rev. - 2002. - 102. P. 2497-2591.

12. Неоганические анионные кислородсодержащие $\alpha$-нуклеофилы - эффективные акцепторы ацильной группы. Гидроксиламин - «лидер» в ряду а-нуклеофилов / Ю. Симаненко, А. Попов, Т. Прокопьева, Е. Карпичев, В. Савелова, И. Супрун, К. Бантон // Журн. орган. химии. - 2002. - 38,№ 9. - С. 1341-1353.

13. The Reactivity of Some Active Nucleophilic Reagents with Organophosphorus Anticholinesterases / Green A., Sainsbury G., Saville B., Stansfield M. // J. Chem. Soc. -1958. - № 4. P. 1583-1587.

14. Kirby A., Younas M. The Reactivity of Phosphate Esters. Reactions of Diesters with $\mathrm{Nu}$ cleophiles // J. Chem. Soc. (B). -1970. - № 6. P. 1165-1172.

15. Jencks W., Gilchrist M. Nonlinear Structure-Reactivity Correlations. The Reactivity of Nucleophilic Reagents toward Esters // J. Am. Chem. Soc. -1968. - 90, № 10. - P. 2622-2637.
16. The a-Effect in Benzyl Transfers from Benzylphenylmethyl Sulfonium Salts to N-Methylbenzohydroxamate Anions / Fountain K., Tady D., Paul T., Golynskiy M., // J. Org. Chem. - 1999. - 64, № 18. - P. 6547-6553.

17. Khairat M., John O., Edwards R. The Mechanism of the Oxidation of Some Aromatic Amines by Peroxyacetic Acid // J. Am. Chem. Soc. -1962 . - 84, № 5. - P. 763-768.

18. Buncel E., Wilson H., Chuaqui C. Reactivity-selectivity correlations. 4 . The a-effect in $\mathrm{S}_{\mathrm{N}} 2$ reactions at $\mathrm{sp}^{3}$ carbon. The reactions of hydrogen peroxide anion with methyl phenyl sulfates // J. Am. Chem. Soc. -1982. -104, № 18. P. 4896-4900.

19. Hoz S., Buncel E. Pitfalls in the determination of the $\alpha$-effect by a two-point analysis. The effect of solvent on the a-effect // Tetrahedron Lett. -1984. - 25, № 32. - P. 3411-3414.

20. Dixon J., Bruice T. Kinetic and thermodynamic nature of the $\alpha$-effect for amine nucleophiles // J. Am. Chem. Soc. -1972. - 94, № 6. - P. 2052-2056.

21. Palling D., Jencks W. Nucleophilic reactivity toward acetyl chloride in water // J. Am. Chem. Soc. - 1984. - 106, № 17. - P. 4869-4876.

22. Jeffrey J., Page M. Buffer catalysis in the hydrazinolysis of benzylpenicillin // J. Chem. Soc., Perkin Trans. 2. - 1980. - P. 220-224.

23. Kinetics of the Reactions of $\beta$-Methoxy- $\alpha$-nitrostilbene with Methoxyamine and N-Methylmethoxyamine. Direct Observation of the Intermediate in Nucleophilic Vinylic Substitution / Bernasconi C., Leyes A., Eventova I., Rappoport Z. // J. Am. Chem. Soc. - 1995. 117, № 6. - P. 1703-1711.

24. Buncel E., Ik-Hwan Um. The a-effect and its modulation by solvent // Tetrahedron Lett. 2004. - 60, № 36. - P. 7801-7825.

25. Absence of an $a$-effect in the gas-phase nucleophilic reactions of hydroperoxide ion / DePuy C., Della E., Filley J., Grabowski J., Bierbaum V. // J. Am. Chem. Soc. - 1983. - 105, № 8. - P. 2481-2482. 
26. Theoretical studies of $S_{N} 2$ transition states, the alpha effect / Saul W., Mitchel D., Schlegel B., Minot C., Eisenstein O. // Tetrahedron Lett. 1982. - 23, № 6. - P. 615-618.

27. The a-Effect in $\mathrm{S}_{\mathrm{N}}$ Ar Substitutions - Reaction between Oximate Nucleophiles and 2,4-Dinitrofluorobenzene in Aqueous Solution / Moutiers G., Guével E., Cannes C., Terrier F., Buncel E. // Europ. J. Org. Chem. - 2001. - № 17. P. 3279-3284.

28. The a-Effect in Reactions of sp-Hybridized Carbon Atom: Michael-Type Reactions of 1-Aryl2-propyn-1-ones with Primary Amines / IkHwan Um, Eun-Ju Lee, Jin-Ah Seok, KyungHee Kim // J. Org. Chem. - 2005. - 70, № 19. P. 7530-7536.

29. The $a$-Effect in Methyl Transfers from S-Methyldibenzothiophenium Fluoroborate to Substituted N-Methylbenzohydroxamates / Fountain K., Felkerson C., Driskell J., Lamp B. // J. Org. Chem. - 2003. - 68, № 5. - P. 18101814.

30. Patterson E., Fountain K. On Gas Phase a-Effects. 1. The Gas-Phase Manifestation and Potential SET Character // J. Org. Chem. - 2006. 71, № 21. - P. 8121-8125.

31. Aubort J., Hudson R. The a-effect of hydroxamic acids // J. Chem. Soc. D: Chem. Commun. 1970. - № 15. - P. 938-939.

32. Effect of modification of the electrophilic center on the a-effect / Ik-Hwan Um, Ji-Youn Lee, Sun-Young Bae, Buncel E. // Can. J. Chem. 2005. - 83. - P. 1365-1371.

33. Predominant role of basicity of leaving group in a-effect for nucleophilic ester cleavage / Nomura Y., Kubozono T., Hidaka M., Horibe M., Mizushima N., Yamamoto N., Takahashi T., Romiyama M. // Bioorg. Chem. - 2004. - 32. P. 26-37.

34. Micellar effects of surfactants in cleavage of 4-nitrophenyl diethylphosphonate by hydroperoxide anion / Solomoichenko T., Sadovskii Y., Prokop'eva T., Karpichev V., Kapitanov I., Pis- kunova Zh., Savelova V., Popov A. // Theoret. and Experim. Chem. -2006. - 42, №. 6. P. 364-370.

35. Peroxyhydrolysis of 4-nitrophenyl diethyl phosphate in micellar systems based on imidazolium gemini surfactants / Sadovskii Y., Solomoichenko T., Turovskaya M., Kapitanov I., Piskunova Zh., Kostrikin M., Prokopeva T., Popov A. // Theoret. and Experim. Chem. 2012. - 48, № 2. - P. 122-128.

36. Reactivity of inorganic a-nucleophiles in acyl group transfer processes in water and sufactant micelles: I. Systems based on organic complexes of tribromide anion / Turovskaya M., Mikhailov V., Burakov N., Kapitanov I., Zubareva T., Lobachev V., Pan chenko B., Prokop'eva T. // Russ. J. Org. Chem. - 2017. - 53, № 3. - P. 351-358.

37. Альберт Л., Сержент Е. Константы ионизации кислот и оснований. - М.: Химия, 1964.

38. Дженкс В. Катализ в химии и энзимологии. - М.: Мир, 1972.

39. The Chlorine-catalyzed Hydrolysis of Isopropyl Methylphosphonofluoride (Sarin) in Aqueous Solution / Epstein J., Baver V., Saxe M., Demek M. // J. Am. Chem. Soc. - 1956. - 78, № 8. P. 4068-4071.

40. Jencks W., Carriuolo J. Reactivity of Nucleophilic Reagents toward Esters // J. Am. Chem. Soc. -1960. - 82, № 7-8. - P. 1778-1786.

41. The Oxibase Scale and Displacement Reactions. XVII. The Reaction of Nucleophiles with Ethyl Tosylate and the Extension of the Oxibase Skale / Davis R., Nehring R., Blume W., Chuang C. // J. Am. Chem. Soc. -1969. - 91, № 1. - P. 91-96.

42. Dixon E., Bruice C. $a$-Effect. IV. Additional Observation on the a-Effect Employing Malachite Green as Substrate // J. Am. Chem. Soc. 1971. - 93, № 24. - P. 6592-6597.

43. Mechanisms of Nucleophilic Substitution Reactions of Methylated Hydroxylamines with Bis(2,4-dinitrophenyl) phosphate. Mass Spectrometric Identification of Key Intermediates / 
Domingos J., Longhinotti E., Brandão T., Bunton C., Santos L., Eberlin M., Nome F. // J. Org. Chem. - 2004. - 69, № 18. - P. 6024-6033.

44. Reactivity of $\mathrm{N}$-alkyl derivatives of hydroxylamine in decomposition of 4-nitrophenyl diethylphosphonate in water and in cetyltrimethylammonium bromide micelles / Zubareva T., Prokop'eva T., Kapitanov I., Belousova I., Razumova N., Popov A. // Theoret. and Experim. Chem. - 2007. - 43, №. 4. - P. 247-254.

45. Characteristic features of the change in reactivity of supernucleophilic functional surfactants in acyl group transfer processes / Prokop'eva T., Karpichev E., Belousova I., Turovskaya M., Shumeiko A., Kostrykin M., Razumova N., Kapitanov I. Popov A. // Theoreret. and Experim. Chem. - 2010. - 46, №. 2. - P. 94-101.

46. From $a$-nucleophiles to functionalized aggregates: exploring the reactivity of hydroxamate ion towards esterolytic reactions in micelles / Singh S., Karpichev Y., Sharma R., Sahu A., Satnami M., Ghosh K. // Org. Biomol. Chem. 2015. - 13. - P. 2827-2848.

47. Hess R., Hengge A., Cleland W. Kinetic Isotope Effects for Acyl Transfer from p-Nitrophenyl Acetate to Hydroxylamine Show a pH-Dependent Change in Mechanism // J. Am. Chem. Soc. - 1997. - 119, № 30. - P. 6980-6983.

48. Брюс Т., Бенкович С. Механизмы биоорганических реакций. - М.: Мир, 1970. - 96 с.

49. Kirby A., Jencks W. The Reactivity of Nucleophilic Reagents toward the $p$-Nitrophenyl Phosphate Dianion // J. Am. Chem. Soc. 1965. - 87, № 14. - P. 3209-3217.

50. Reactions of Phosphate Acid Esters with $\mathrm{Nu}-$ cleophiles. II. Survey of Nucleophiles Reacting with $p$-Nitrophenyl Methyl Phosphonate Anion / Behrmann E., Biallas M., Brass H., Edwards J., Isaaks M. // J. Org. Chem. - 1970. 35, № 9. - P. 3069-3070.

51. Davies D., Deary M. A convenient preparation of aqueous methyl hydroperoxide and a comparison of its reactivity towards triacetyleth- ylenediamine with that of other nucleophiles: the mechanism of peroxide bleach activation // J. Chem. Soc., Perkin Trans 2. - 1992. - № 4. P. 559-562.

52. Sander E., Jencks W. General acid and base catalysis of the reversible addition of hydrogen peroxide to aldehydes // J. Am. Chem. Soc. 1968. -90, № 16. -P. 4377 - 4386.

53. Cholinesterase Reactivation in Vivo with a Novel Bis-Oxime Optimized by Computer-Aided Design / Hammond P., Kern C., Hong F., Kollmeyer T., Pang Y., Brimijoin S. // J. Pharmacol. Experim. Therap. - 2003. - 307, № 1. - P. 190-196.

54. Oxime-Induced Reactivation of Sarin-Inhibited AchE: A Theoretical Mechanisms Study / Wang J, Gu J., Leszczynski J., Feliks M., Sokalski W. // J. Phys. Chem. B. - 2007. - 111, № 9. P. 2404-2408.

55. Progress in Synthesis of New Acetylcholinesterase Reactivators During the Period 1990-2004 / Musilek K., Kuca K., Jun D., Dolezal M. // Current Org. Chem. - 2007. - 11, № 2. - P. 229-238.

56. The Development of New Structural Analogues of Oximes for the Antidotal Treatment of Poisoning by Nerve Agents and the Comparison of Their Reactivating and Therapeutic Efficacy with Currently Available Oximes / Kassa J., Kuca K., Bartosova L., Kunesova G. // Current Org. Chem. - 2007. - 11, № 2. - P. 267-283.

57. Monooxime reactivators of acetylcholinesterase with (E)-but-2-ene linker - Preparation and reactivation of tabun- and paraoxon-inhibited acetylcholinesterase / Musilek K., Holas O., Jun G., Dohnal V., Gunn-Moore F., Opletalova V., Dolezal M., Kuca K. // Bioorg. Med. Chem. 2007. - 15, № 21. - P. 6733-6741.

58. New oxime reactivators connected with $\mathrm{CH}_{2} \mathrm{O}\left(\mathrm{CH}_{2}\right)_{\mathrm{n}} \mathrm{OCH}_{2}$ linker and their reactivation potency for organophosphorus agents-inhibited acetylcholinesterase / Yang G., Oh K., Park N., Jung Y. // Bioorg. Med. Chem. 2007. - 15, № 24. - P. 7704-7710. 
59. Monoquaternary pyridinium salts with modified side chain-synthesis and evaluation on model of tabun- and paraoxon-inhibited acetylcholinesterase / Musilek K., Kucera J., Jun D., Dohnal V., Opletalova V., Kuca K. // Bioorg. Med. Chem. - 2008. - 16, № 17. - P. 8218-8223.

60. Design of a Potent Reactivator of Tabun-Inhibited Acetylcholinesterase-Synthesis and Evaluation of (E)-1-(4-Carbamoylpyridinium)-4-(4hydroxyiminomethylpyridinium)-but-2-ene Dibromide (K203) / Musilek K., Jun D., Cabal J., Kassa J., Gunn-Moore F., Kuca K. // J. Med. Chem. - 2007. - 50, № 22. - P. 5514-5518.

61 . Revisiting the reactivity of oximate $\alpha$-nucleophiles with electrophilic phosphorus centers. Relevance to detoxification of sarin, soman and DFP under mild conditions / Terrier F., Rodriguez-Dafonte P., Guével E., Moutiers G. // Org. Biomol. Chem. - 2006. - 4, № 23. - P. 43524363.

62. Нуклеофильное замещение у тетракоординированного атома серы VI. Реакционная способность оксимат-ионов / Прокопьева Т., Симаненко Ю., Супрун И., Савелова В., Зубарева Т., Карпичев Е. // Журн. орган. химии. - 2001. - 37, № 5. - С. 694-704.

63. Reactivity of functional detergents with a pyridine ring and an a-nucleophile fragment in the head group / Belousova I., Kapitanov I., Shumeiko A., Mikhailov V., Razumova N., Prokop'eva T., Popov A. // Theoret. and Experim. Chem. - 2008. - 44, № 5. - P. 292-299.

64. Supernucleophilic systems based on functionalized surfactants in the decomposition of 4-nitrophenyl esters derived from phosphorus and sulfur acids: I. Reactivity of a hydroxyimino derivative of gemini imidazolium surfactant / Kapitanov I., Belousova I., Shumeiko A., Kostrikin M., Prokop'eva T., Popov A. // Russ. J. Org. Chem. - 49, № 9. P. 1291-1299.

65. Nonlinear Bronsted Correlations: The Roles of Resonance, Solvation and Changing Tran-
sion-State Structure / Jencks W., Brant S., Gandler J., Fendrich G., Nakamura C. // J. Am. Chem. Soc. - 1982. - 104, № 25. - P. 70457051.

66. Нуклеофильное замещение у тетракоординационного атома серы. III. Реакционная способность анионных кислородсодержащих нуклеофилов - арилат - и алкоголятионов / Симаненко Ю., Прокопьева Т., Савелова В., Закаличная О., Белоусова И., Попов А., Саккулин Г. // Реакц. способн. орган. соедин. - 1989. - 26, №.1. - С. 30-54.

67. Нуклеофильное замещение у тетракоординированного атома серы. IV. Реакционная способность анионных азотсодержащих нуклеофилов / Савелова В., Карпичев Е., Симаненко Ю., Прокопьева Т., Лобачев Л., Белоусова И. // Журн. орган. химии. 1996. - 32, № 4. - С. 551-560.

68. Chemical Warfare Agent Degradation and Decontamination / Talmage S., Watson A., Hauschild V., Munro N., King J. // Current Org. Chem. - 2007. - 11, № 3. - P. 285-298.

69. Decontamination of VX, GD, and HD on a Surface Using Modified Vaporized Hydrogen Peroxide / Wagner G., Sorrick D., Procell L., Brickhouse M., Mcvey I., Schwartz L. // Langmuir. - 2007. - 23, № 3. - P. 1178-1186.

70. Destruction of Chemical Warfare Agents VX and Soman by $a$-Nucleophiles as Oxidizing Agents / Cassgne T., Cristau H., Delmas G., Desgranges M., Lion G., Magnaud G., Torreilles T., Virieux D. // Heteroatom Chem. 2001. - 12, № 6. - P. 485-490.

71. Wagner G., Yu-Chu Yang. Rapid Nucleophilic/ Oxidative Decontamination of Chemical Warfare Agents // Ind. Eng. Chem. Res. - 2002. 41, № 8. - P. 1925-1928.

72. Пат. US 006245957 B1. Universal Decontaminating Solution for Chemical Warfare Agents / Wagner G., Yu-Chu Yang. - Опубл. 2001.

73. Пат. US 006723891 B1. Molybdate/Peroxide Microemulsions useful for Decontamination 
of Chemical Warfare Agents / Wagner G, Procell L., Yu-Chu Yang and other. -Опубл. 2004.

74. Aubry J., Bouttemy S. Preparative Oxidation of Organic Compounds in Microemulsions with Singlet Oxygen Generated Chemically by the Sodium Molybdate / Hydrogen Peroxide System // J. Am. Chem. Soc. -1997. - 119, № 23. P. 5286-5294.

75. Acetylcholinesterase reactivators based on oxime-functionalized biodegradable ionic liquids / Karpichev E., Kapitanov I., Gathergood N., Soukup O., Hepnarova V., Jun D., Kuča K. // Military Medical Science Letters. - 2018. - 87, № 1 . - P. 87.

76. Marrs T., Ballantyne B. Pesticide Toxicology and International Regulation. - England: John Wiley \& Sons, Ltd., 2004.

77. Marrs T., Maynard R., Sidell F. Chemical Warfare Agents: Toxicology and Treatment. - England: John Wiley \& Sons Ltd., 2007.

78. Франке 3. Химия отравляющих веществ. М.: Химия, 1973.

79. Машковский М. Лекарственные средства. М.: Медицина, 1998.

80. Nonquaternary cholinesterase reactivators. 2 . a-Heteroaromatic aldoximes and thiohydroximates as reactivators of ethyl methylphosphonyl-acetylcholinesterase in vitro / Kenley R., Bedford C., Dailey O. Howd J., Miller A. // J. Med. Chem. - 1984. - 27, № 9. - P. 12011211.

81. Tarkka R., Buncel E. Origin of the Bell-Shaped a-Effect-Solvent Composition Plots. pKa-Solvent Dependence of the $\alpha$-Effect at a Phosphorus Center // J. Am. Chem. Soc. -1995. - 117, № 5. - P. 1503-1507.

82. The levelling effect of solvational imbalances in the reactions of oximate -nucleophiles with electrophilic phosphorus centers. Relevance to detoxification of organophosphorus esters / Terrier F., Guével E., Chatrousse A., Moutiers G., Buncel E. // Chem. Commun. - 2003. № 5. - P. 600-601.
83. Degorre F., Kiffer D., Terrier F. Sulfur derivatives of 2-oxopropanal oxime as reactivators of organophosphateinhibied acetylcholinesterase in vitro: synthesis and structure-reactivity relationships // J. Med. Chem. - 1988. - 31, № 4. - P. 757-763.

84. Green A., Saville B. The reaction of oximes with isopropyl methylphosphono-fluoridate (Sarin) // J. Chem. Soc. - 1956. - P. 3887-3892.

85. Degradation of the pesticide fenitrothion as mediated by cationic surfactants and $\alpha$-nucleophilic reagents / Han X., Balakrishnan V., Loon G., Buncel E. // Langmuir. - 2006. - 22, №. 21 - P. 9009-9017.

86. Han X., Balakrishnan V., Buncel E. Alkaline Degradation of the Organophosphorus Pesticide Fenitrothion as Mediated by Cationic $\mathrm{C}_{12}, \mathrm{C}_{14}, \mathrm{C}_{16}$, and $\mathrm{C}_{18}$ Surfactants // Langmuir. 2007. - 23, № 12. - P. 6519-6525.

87. Acceleration of Nucleophilic Attack on an Organophosphorothioate Neurotoxin, Fenitrothion, by Reactive Counterion Cationic Micelles. Regioselectivity as a Probe of Substrate Orientation within the Micelle / Balakrishnan M., Han X., Loon G., Dust J., Toullec J., Buncel E. // Langmuir. - 2004. - 20, № 16. P. 6586-6593.

88. Mechanisms of abiotic degradation and soilwater interactions of pesticides and other hydrophobic organic compounds. Part 3. Nucleophilic displacement at the phosphorrus centre of the pesticide fenitrothion [O, O-dimethyl O-(3-methyl-4-nitrophenyl) phosphorothioate] by oxygen nucleophiles in aqueous solution: $\alpha$-effect and mechanism / Omakor J., Onyido I., Loon G., Buncel E. // J. Chem. Soc., Perkin Trans. 2. - 2001. - № 3. - P. 324-330.

89. Sidell F., Groff W. The Reactivatibility of Cholinesterase Inhibited by VX and Sarin in Man // Toxicol. Appl. Pharmacol. -1974. - 27. P. 241-252.

90. Toxicity of Parathion, Systox, Octamethyl Pyrophosphoramide, and Methyl Parathion in 
Man / Rider J., Moeller H., Puletti E., Swader J. // Toxicol. Appl. Pharmacol. - 1969. 14. - P. 603-611.

91. Grossblatt N. Possible Long-Term Health Effects of Short-Term Exposure to Chemical Agents. -Washington: National Academy Press. - 1982. 1. - 296 p. - 1984. - 2. - 330 c.

92. Analysis of inhibition, reactivation and aging kinetics of highly toxic organophosphorus compounds with human and pig acetylcholinesterase / Aurbek N., Thiermann H., Szinicz L., Eyer P., Worek V. // Toxicology. - 2006. 224, № 1-2. - P. 91-99.

93. Reiner E., Simeon-Rudolf V. Pyridinium, imidazolium and quinuclidinium compounds: toxicity and antidotal effects against the nerve agents tabun and soman // Arh. Hig. Rada Toxicol. - 2006. - 57. - P. 171-179.

\section{REFERENCES}

1. John O., Edwards R., Pearson G. The Factors Determining Nucleophilic Reactivities. J. Am. Chem. Soc. 1962.84 (1): 16.

2. Nick J., John O. Edwards R. The Alpha Effect. Review. International J. Chem. kinetics. 1973. 5: 1 .

3. Popov A., Savelova V. Modern approaches to the design of highly efficient nucleophilic systems. Theoret. and Experim. Chem. 1999. 35 (1): 1 .

4. Popov A. Design of green microorganized systems for decontamination of ecotoxicants. Pure Appl. Chem. 2008.80 (7): 1381.

5. Yu-Chu Y., James A., Baker J. Ward R. Decontamination of Chemical Warfare Agents. Chem. Rev. 1992.92 (8): 1729.

6. Grekov A., Veselov V. $a$-Effect in the chemistry of organic compounds. Advances in Chem. 1978. 47 (7): 1200.
7. Séguès B., Pérez E., Rico-Lattes I., Rivière M., Lattes A. Décontamination chimique. I. Déphosphorylation des composés organophosphorés. Bull. Soc. Chim. Fr. 1996. 133: 925.

8. Latt A., Rico-Latt I., Perez E., Krutikov V., Amada $B$. The use of organized molecular systems for the chemical decomposition of chemical warfare agents. J. Russ. Chem. Society to them D. Mendeleev. 2007. 51 (6): 36.

9. Popov A., Prokopieva T., Suprun I., Simanenko Y. The reactivity of inorganic nucleophiles in the transfer of phosphoryl and phosphonyl groups. Theoret. and Experim. Chem. 2000. 36 (4): 226.

10. Rappoport E., Liebmann J. The chemistry of Hydroxylamines, Oximes and Hydroxamic Acids. (England: John Wiley \& Sons Ltd., 2009).

11. Morales-Rojas H., Moss R. Phosphorolytic Reactivity of o-Iodosylcarboxylates and Related Nucleophiles. Chem. Rev. 2002. 102: 2497.

12. Simanenko Y., Popov A., Prokopyeva T., Karpichev E., Savelova V., Suprun I., Banton K. Neo-organic anionic oxygen-containing nucleophiles are effective acceptors of the acyl group. Hydroxylamine - the «leader» in the series of a-nucleophiles. Russ. J. Org. Chem. 2002. 38 (9): 1341.

13. Green A., Sainsbury G., Saville B., Stansfield M. The Reactivity of Some Active Nucleophilic Reagents with Organophosphorus Anticholinesterases. J. Chem. Soc. 1958. (4): 1583.

14. Kirby A., Younas M. The Reactivity of Phosphate Esters. Reactions of Diesters with $\mathrm{Nu}$ cleophiles. J. Chem. Soc. (B). 1970. (6): 1165.

15. Jencks W., Gilchrist M. Nonlinear Structure-Reactivity Correlations. The Reactivity of Nucleophilic Reagents toward Esters. J. Am. Chem. Soc. 1968.90 (10): 2622.

16. Fountain K., Tady D., Paul T., Golynskiy M. The a-Effect in Benzyl Transfers from Benzylphenylmethyl Sulfonium Salts to N-Methylbenzohydroxamate Anions. J. Org. Chem. 1999. 64 (18): 6547. 
17. Khairat M., John O., Edwards R. The Mechanism of the Oxidation of Some Aromatic Amines by Peroxyacetic Acid. J. Am. Chem. Soc. 1962.84 (5): 763.

18. Buncel E., Wilson H., Chuaqui C. Reactivity-selectivity correlations. 4 . The a-effect in $\mathrm{S}_{\mathrm{N}} 2$ reactions at $\mathrm{sp}^{3}$ carbon. The reactions of hydrogen peroxide anion with methyl phenyl sulfates. J. Am. Chem. Soc. 1982. 104 (18): 4896.

19. Hoz S., Buncel E. Pitfalls in the determination of the $\alpha$-effect by a two-point analysis. The effect of solvent on the a-effect. Tetrahedron Lett. 1984. 25 (32): 3411.

20. Dixon J., Bruice T. Kinetic and thermodynamic nature of the a-effect for amine nucleophiles. J. Am. Chem. Soc. 1972.94 (6): 2052.

21. Palling D., Jencks W. Nucleophilic reactivity toward acetyl chloride in water. J. Am. Chem. Soc. 1984. 106 (17): 4869.

22. Jeffrey J., Page M. Buffer catalysis in the hydrazinolysis of benzylpenicillin. J. Chem. Soc., Perkin Trans. 2. 1980. 220.

23. Bernasconi C., Leyes A., Eventova I., Rappoport Z. Kinetics of the Reactions of $\beta$-Methoxy-a-nitrostilbene with Methoxyamine and N-Methylmethoxyamine. Direct Observation of the Intermediate in Nucleophilic Vinylic Substitution. J. Am. Chem. Soc. 1995. 117 (6): 1703 .

24. Buncel E., Ik-Hwan Um. The a-effect and its modulation by solvent. Tetrahedron Lett. 2004. 60 (36): 7801.

25. DePuy C., Della E., Filley J., Grabowski J., Bierbaum V. Absence of an a-effect in the gasphase nucleophilic reactions of hydroperoxide ion. J. Am. Chem. Soc. 1983. 105 (8): 2481.

26. Saul W., Mitchel D., Schlegel B., Minot C., Eisenstein $\mathrm{O}$. Theoretical studies of $\mathrm{S}_{\mathrm{N}} 2$ transition states, the alpha effect. Tetrahedron Lett. 1982. 23 (6): 615.

27. Moutiers G., Guével E., Cannes C., Terrier F., Buncel E. The a-Effect in $S_{N}$ Ar Substitutions Reaction between Oximate Nucleophiles and
2,4-Dinitrofluorobenzene in Aqueous Solution. Europ. J. Org. Chem. 2001. (17): 3279.

28. Ik-Hwan Um, Eun-Ju Lee, Jin-Ah Seok, KyungHee Kim. The a-Effect in Reactions of sp-Hybridized Carbon Atom: Michael-Type Reactions of 1-Aryl-2-propyn-1-ones with Primary Amines. J. Org. Chem. 2005. 70 (19): 7530.

29. Fountain K., Felkerson C., Driskell J., Lamp B. The a-Effect in Methyl Transfers from S-Methyldibenzothiophenium Fluoroborate to Substituted $\mathrm{N}$-Methylbenzohydroxamates. J. Org. Chem. 2003. 68 (5): 1810.

30. Patterson E., Fountain K. On Gas Phase a-Effects. 1. The Gas-Phase Manifestation and Potential SET Character. J. Org. Chem. 2006. 71 (21): 8121.

31. Aubort J., Hudson R. The a-effect of hydroxamic acids. J. Chem. Soc. D: Chem. Commun. 1970. (15): 938.

32. Ik-Hwan Um, Ji-Youn Lee, Sun-Young Bae, Buncel E. Effect of modification of the electrophilic center on the a-effect. Can. J. Chem. 2005. 83: 1365.

33. Nomura Y., Kubozono T., Hidaka M., Horibe M., Mizushima N., Yamamoto N., Takahashi T., Romiyama M. Predominant role of basicity of leaving group in a-effect for nucleophilic ester cleavage. Bioorg. Chem. 2004. 32: 26.

34. Solomoichenko T., Sadovskii Y., Prokop'eva T., Karpichev Y., Kapitanov I., Piskunova Zh., Savelova V., Popov A. Micellar effects of surfactants in cleavage of 4-nitrophenyl diethylphosphonate by hydroperoxide anion. Theoret. and Experim. Chem. 206. 42 (6): 364.

35. Sadovskii Y., Solomoichenko T., Turovskaya M., Kapitanov I., Piskunova Zh., Kostrikin M., Prokopeva T., Popov A. Peroxyhydrolysis of 4-nitrophenyl diethylphosphate in micellar systems based on imidazolium gemini surfactants. Theoret. and Experim. Chem. 2012. 48 (2): 122.

36. Turovskaya M., Mikhailov V., Burakov N., Kapitanov I., Zubareva T., Lobachev V., Panchenko B., 
Prokop'eva T. Reactivity of inorganic $\alpha$-nucleophiles in acylgroup transfer processes in water and surfactant micelles: I. Systems based on organic complexes of tribromide anion. Russ. J. Org. Chem. 2017.53 (3): 351.

37. Albert L., Sergeant E. Ionization constants of acids and bases. (M.: Khimiya, 1964). [in Russian].

38. Jenks W. Catalysis in chemistry and enzymology.. (M.: Mir, 1972). [in Russian].

39. Epstein J., Baver V., Saxe M., Demek M. The Chlorine-catalyzed Hydrolysis of Isopropyl Methylphosphonofluoride (Sarin) in Aqueous Solution. J. Am. Chem. Soc. 1956. 78 (8): 4068.

40. Jencks W., Carriuolo J. Reactivity of Nucleophilic Reagents toward Esters. J. Am. Chem. Soc. 1960. 82 (7-8): 1778.

41. Davis R., Nehring R., Blume W., Chuang C. The Oxibase Scale and Displacement Reactions. XVII. The Reaction of Nucleophiles with Ethyl Tosylate and the Extension of the Oxibase Skale. J. Am. Chem. Soc. 1969. 91(1): 91.

42. Dixon E., Bruice C. a-Effect. IV. Additional Observation on the a-Effect Employing Malachite Green as Substrate. J. Am. Chem. Soc. 1971.93 (24): 6592.

43. Domingos J., Longhinotti E., Brandão T., Bunton C., Santos L., Eberlin M., Nome F. Mechanisms of Nucleophilic Substitution Reactions of Methylated Hydroxylamines with Bis(2,4-dinitrophenyl) phosphate. Mass Spectrometric Identification of Key Intermediates. J. Org. Chem. 2004.69 (18): 6024.

44. Zubareva T., Prokopeva T., Kapitanov I., Belousova I., Razumova N., Popov A. Reactivity of $\mathrm{N}$-alkyl derivatives of hydroxylamine in decomposition of 4-nitrophenyl diethylphosphonate in water and in cetyltrimethylammonium bromide micelles. Theoret. and Experim. Chem. 2007. 43 (4): 247.

45. Prokop'eva T., Karpichev E., Belousova I., Turovskaya M., Shumeiko A.,Kostrykin M., Razumova N., Kapitanov I. Popov A. Char- acteristic features of the change in reactivity of supernucleophilic functional surfactants in acyl group transfer proceses. Theoret. Theoret. and Experim. Chem. 2010. 46 (2): 94.

46. Singh S., Karpichev Y., Sharma R., Sahu A., Satnami M., Ghosh K. From a-nucleophiles to functionalized aggregates: exploring the reactivity of hydroxamate ion towards esterolytic reactions in micelles. Org. Biomol. Chem. 2015. 13: 2827.

47. Hess R., Hengge A., Cleland W. Kinetic Isotope Effects for Acyl Transfer from p-Nitrophenyl Acetate to Hydroxylamine Show a pH-Dependent Change in Mechanism. J. Am. Chem. Soc. 1997. 119 (30): 6980.

48. Bruce T., Benkovich S. Mechanisms of bioorganic reactions. (M.: Mir, 1970). [in Russian].

49. Kirby A., Jencks W. The Reactivity of Nucleophilic Reagents toward the $p$-Nitrophenyl Phosphate Dianion. J. Am. Chem. Soc. 1965. 87 (14): 3209.

50. Behrmann E., Biallas M., Brass H., Edwards J., Isaaks M. Reactions of Phosphate Acid Esters with Nucleophiles. II. Survey of Nucleophiles Reacting with $p$-Nitrophenyl Methyl Phosphonate Anion. J. Org. Chem. 1970. 35 (9): 3069.

51. Davies D., Deary M. A convenient preparation of aqueous methyl hydroperoxide and a comparison of its reactivity towards triacetylethylenediamine with that of other nucleophiles: the mechanism of peroxide bleach activation. J. Chem. Soc., Perkin Trans 2. 1992. (4): 559.

52. Sander E., Jencks W. General acid and base catalysis of the reversible addition of hydrogen peroxide to aldehydes. J. Am. Chem. Soc. 1968. 90 (16): 4377.

53. Hammond P., Kern C., Hong F., Kollmeyer T., Pang Y., Brimijoin S. Cholinesterase Reactivation in Vivo with a Novel Bis-Oxime Optimized by Computer-Aided Design. J. Pharmacol. Experim. Therap. 2003.307 (1): 190.

54. Wang J, Gu J., Leszczynski J., Feliks M., Sokalski W. Oxime-Induced Reactivation of Sarin- 
Inhibited AchE: A Theoretical Mechanisms Study. J. Phys. Chem. B. 2007. 111 (9): 2404.

55. Musilek K., Kuca K., Jun D., Dolezal M. Progress in Synthesis of New Acetylcholinesterase Reactivators During the Period 1990-2004. Current Org. Chem. 2007. 11 (2): 229.

56. Kassa J., Kuca K., Bartosova L., Kunesova G. The Development of New Structural Analogues of Oximes for the Antidotal Treatment of Poisoning by Nerve Agents and the Comparison of Their Reactivating and Therapeutic Efficacy with Currently Available Oximes. Current Org. Chem. 2007. 11 (2): 267.

57. Musilek K., Holas O., Jun G., Dohnal V., GunnMoore F., Opletalova V., Dolezal M., Kuca K. Monooxime reactivators of acetylcholinesterase with (E)-but-2-ene linker - Preparation and reactivation of tabun- and paraoxon-inhibited acetylcholinesterase. Bioorg. Med. Chem. 2007.15 (21): 6733.

58. Yang G., Oh K., Park N., Jung Y. New oxime reactivators connected with $\mathrm{CH}_{2} \mathrm{O}\left(\mathrm{CH}_{2}\right)_{n}$ $\mathrm{OCH}_{2}$ linker and their reactivation potency for organophosphorus agents-inhibited acetylcholinesterase. Bioorg. Med. Chem. 2007. 15 (24): 7704.

59. Musilek K., Kucera J., Jun D., Dohnal V., Opletalova V., Kuca K. Monoquaternary pyridinium salts with modified side chain-synthesis and evaluation on model of tabun- and paraoxon-inhibited acetylcholinesterase. Bioorg. Med. Chem. 2008. 16 (17). 8218.

60. Musilek K., Jun D., Cabal J., Kassa J., GunnMoore F., Kuca K. Design of a Potent Reactivator of Tabun-Inhibited Acetylcholinesterase-Synthesis and Evaluation of (E)-1-(4-Carbamoylpyridinium)-4-(4-hydroxyiminomethylpyridinium)-but-2-ene-dibromide (K203). J. Med. Chem. 2007.50 (22): 5514.

61. Terrier F., Rodriguez-Dafonte P., Guével E., Moutiers G. Revisiting the reactivity of oximate a-nucleophiles with electrophilic phosphorus centers. Relevance to detoxification of sarin, soman and DFP under mild conditions. Org. Biomol. Chem.2006. 4 (23): 4352.

62. Prokopyeva T., Simanenko Yu., Suprun I., Savelova V., Zubareva T., Karpichev E. Nucleophilic substitution at the tetracoordinated sulfur atom VI. The reactivity of oximeate ions. Russ. J. Org. Chem. 2001.37 (5): 694.

63. Belousova I., Kapitanov I., Shumeiko A., Mikhailov V., Razumova N., Prokopeva T., Popov A. Reactivity of functional detergents with a pyridine ring and an $\alpha$-nucleophile fragment in the head group. Theoret. and Experim. Chem. 2008. 44 (5): 292.

64. Kapitanov I., Belousova I., Shumeiko A., Kostrikin M., Prokopeva T., Popov A. Supernucleophilic systems based on functionalized surfactants in the decompositi on of hydroxyimino derivative of gemini imidazolium surfactant. Russ. J. Org. Chem. 2013. 49 (9): 1291.

65. Jencks W., Brant S., Gandler J., Fendrich G., Nakamura C. Nonlinear Bronsted Correlations: The Roles of Resonance, Solvation and Changing Transion-State Structure. J. Am. Chem. Soc. 1982. 104 (25): 7045.

66. Simanenko Yu., Prokopyeva T., Savelova V., Zakalichnaya O., Belousova I., Popov A., Sakkulin G. Nucleophilic substitution at the tetracoordinating sulfur atom. III. Reactivity of anionic oxygen-containing nucleophiles - arylate and alcoholate ions. Reakt. capable organ. connection. 1989. 26 (1): 30.

67. Savelova V., Karpichev E., Simanenko Yu., Prokopyeva T., Lobachev L., Belousova I. Nucleophilic substitution at a tetracoordinated sulfur atom. IV. The reactivity of anionic nitrogen-containing nucleophiles. Russ. J. Org. Chem. 1996. 32 (4): 551.

68. Talmage S., Watson A., Hauschild V., Munro N., King J. Chemical Warfare Agent Degradation and Decontamination. Current Org. Chem. 2007. 11 (3): 285.

69. Wagner G., Sorrick D., Procell L., Brickhouse M., Mcvey I., Schwartz L. Decontamination of VX, 
GD, and HD on a Surface Using Modified Vaporized Hydrogen Peroxide. Langmuir. 2007. 23 (3): 1178.

70. Cassgne T., Cristau H., Delmas G., Desgranges M., Lion G., Magnaud G., Torreilles T., Virieux D. Destruction of Chemical Warfare Agents VX and Soman by a-Nucleophiles as Oxidizing Agents. Heteroatom Chem. - 2001. - 12, № 6. P. 485-490.

71. Wagner G., Yu-Chu Yang. Rapid Nucleophilic/ Oxidative Decontamination of Chemical Warfare Agents. Ind. Eng. Chem. Res. 2002. 41 (8). 1925.

72. Patent US 006245957 B1. Wagner G., Yu-Chu Yang. Universal Decontaminating Solution for Chemical Warfare Agents. 2001.

73. Patent US 006723891 B1. Wagner G, Procell L., Yu-Chu Yang and other. Molybdate/Peroxide Microemulsions useful for Decontamination of Chemical Warfare Agents. 2004.

74. Aubry J., Bouttemy S. Preparative Oxidation of Organic Compounds in Microemulsions with Singlet Oxygen Generated Chemically by the Sodium Molybdate / Hydrogen Peroxide System. J. Am. Chem. Soc. 1997. 119 (23): 5286.

75. Karpichev E., Kapitanov I., Gathergood N., Soukup O., Hepnarova V., Jun D., Kusa A., Acetylcholinesterase reactivators based on oxime-functionalized biodegradable ionic liquids. Military Medical Science Letters. 2018. 87 (1): 87.

76. Marrs T., Ballantyne B. Pesticide Toxicology and International Regulation. (England: John Wiley \& Sons Ltd., 2004).

77. Marrs T., Maynard R., Sidell F. Chemical Warfare Agents: Toxicology and Treatment. (England: John Wiley \& Sons Ltd., 2007).

78. Franke Z. Chemistry of toxic substances. REFERENCES REFERENCES - M.: Khimiya, 1973). [in Russian].

79. Mashkovsky M. Drugs. - M.: Medicine, 1998. [in Russian].

80. Kenley R., Bedford C., Dailey O. Howd J.,
Miller A. Nonquaternary cholinesterase reactivators. 2. a-Heteroaromatic aldoximes and thiohydroximates as reactivators of ethyl methylphosphonyl-acetylcholinesterase in vitro. J. Med. Chem. 1984. 27 (9): 1201.

81. Tarkka R., Buncel E. Origin of the Bell-Shaped a-Effect-Solvent Composition Plots. pKa-Solvent Dependence of the $\alpha$-Effect at a Phosphorus Center. J. Am. Chem. Soc. 1995. 117 (5): 1503.

82. Terrier F., Guével E., Chatrousse A., Moutiers G., Buncel E. The levelling effect of solvational imbalances in the reactions of oximate -nucleophiles with electrophilic phosphorus centers. Relevance to detoxification of organophosphorus esters. Chem. Commun. 2003. (5): 600.

83. Degorre F. Degorre F., Kiffer D., Terrier F. Sulfur derivatives of 2-oxopropanal oxime as reactivators of organophosphate-inhibited acetylcholinesterase in vitro: synthesis and structure-reactivity relationships. J. Med. Chem. 1988. 31 (4): 757.

84. Green A., Saville B. The reaction of oximes with isopropyl methylphosphono-fluoridate (Sarin). J. Chem. Soc. 1956. 3887.

85. Han X., Balakrishnan V., Loon G., Buncel E. Degradation of the pesticide fenitrothion as mediated by cationic surfactants and $\alpha$-nucleophilic reagents. Langmuir. 2006. 22 (21): 9009.

86. Han X., Balakrishnan V., Buncel E. Alkaline Degradation of the Organophosphorus Pesticide Fenitrothion as Mediated by Cationic $\mathrm{C}_{12}$, $\mathrm{C}_{14}, \mathrm{C}_{16}$, and $\mathrm{C}_{18}$ Surfactants. Langmuir. 2007. 23 (12): 6519.

87. Balakrishnan M., Han X., Loon G., Dust J., Toullec J., Buncel E. Acceleration of Nucleophilic Attack on an Organophosphorothioate Neurotoxin, Fenitrothion, by Reactive Counterion Cationic Micelles. Regioselectivity as a Probe of Substrate Orientation within the Micelle. Langmuir. 2004. 20 (16): 6586. 
88. Omakor J., Onyido I., Loon G., Buncel E. Mechanisms of abiotic degradation and soilwater interactions of pesticides and other hydrophobic organic compounds. Part 3. Nucleophilic displacement at the phosphorrus centre of the pesticide fenitrothion $[\mathrm{O}, \mathrm{O}-\mathrm{di}-$ methyl O-(3-methyl-4-nitrophenyl) phosphorothioate] by oxygen nucleophiles in aqueous solution: a-effect and mechanism. J. Chem. Soc., Perkin Trans. 2. 2001. (3): 324.

89. Sidell F., Groff W. The Reactivatibility of Cholinesterase Inhibited by VX and Sarin in Man. Toxicol. Appl. Pharmacol. 1974. 27: 241.

90. Rider J., Moeller H., Puletti E., Swader J. Toxicity of Parathion, Systox, Octamethyl Pyrophosphoramide, and Methyl Parathion in Man. Toxicol. Appl. Pharmacol. 1969. 14: 603.
91. Grossblatt N. Possible Long-Term Health Effects of Short-Term Exposure to Chemical Agents. (Washington: National Academy Press, 1982. 1., 1984. 2 ).

92. Aurbek N., Thiermann H., Szinicz L., Eyer P., Worek V. Analysis of inhibition, reactivation and aging kinetics of highly toxic organophosphorus compounds with human and pig acetyl cholinesterase. Toxicology. 2006. 224 (1-2): 91.

93. Reiner E., Simeon-Rudolf V. Pyridinium, imidazolium and quinuclidinium compounds: toxicity and antidotal effects against the nerve agents tabun and soman. Arh. Hig. Rada Toxicol. 2006. 57: 171.

Статья направлена в редакцию «24» марта 2020 года. 